\title{
Review
}

\section{Public Responses to Airborne Wind Energy: A Literature Review}

\author{
Helena Schmidt ${ }^{1}{ }^{*}$, Gerdien de Vries ${ }^{2}$, Reint Jan Renes ${ }^{3}$ and Roland Schmehl ${ }^{1}$ \\ 1 Faculty of Aerospace Engineering, Delft University of Technology (TU Delft), 2629 HS Delft, The \\ Netherlands; h.s.schmidt@tudelft.nl/ r.schmehl@tudelft.nl \\ 2 Faculty of Technology, Policy and Management, TU Delft, 2628 BX Delft, The Netherlands; \\ g.devries-2@tudelft.nl \\ 3 Faculty of Applied Social Sciences and Law, Amsterdam University of Applied Sciences, $1091 \mathrm{GH}$ \\ Amsterdam, The Netherlands; r.j.renes@hva.nl \\ * Correspondence: h.s.schmidt@tudelft.nl
}

\begin{abstract}
Airborne wind energy (AWE) systems use tethered flying devices to harvest higheraltitude winds to produce electricity. For a successful deployment of these systems, it is crucial to understand how the public perceives them. If public concerns about the technology are not taken seriously, implementation could be delayed or, in some cases, prevented, resulting in increased costs for project developers and a lower contribution of the sector to renewable energy targets. This literature review assessed the current state of knowledge on public responses to AWE. An exhaustive literature search led to the identification of 40 relevant publications that were reviewed. The literature assumed that the safety, visibility, acoustic emissions, ecological impacts, and the siting of AWE systems shape public responses to the technology. The reviewed literature views people's responses to AWE very optimistically but lacks scientific evidence to back up its claims. It seems to overlook that the influence of AWE's characteristics (e.g., visibility) on public responses will also depend on a range of situational and psychological factors (e.g., people's general attitude towards AWE, the public's trust in project developers). Therefore, empirical social scientific research is needed to increase the field's understanding of public responses to AWE and thereby facilitate deployment.
\end{abstract}

Keywords: airborne wind energy; renewable energy; public response; perception; acceptance; acceptability; opposition

\section{Introduction}

Airborne wind energy (AWE) is an emerging wind energy technology. With AWE systems, higher-altitude winds (generally $300-600 \mathrm{~m}$ above the ground) can be harvested using tethered flying devices [1]. For the sake of brevity, we will refer to the flying devices as kites. A variety of different AWE systems exist, which can be categorized according to the following three aspects: electricity generation (ground-gen, fly-gen), kite system (softwing, fixed-wing, hybrid-wing), and flight operation (crosswind, tether aligned, rotational) [2-4]. Regarding electricity generation, some kites produce electricity through on-board generators and transmit it with a conducting tether to the ground (fly-gen), while others convert the lift forces of the kite into electricity on the ground using either a fixed or a moving (e.g., rotating) ground station (ground-gen) [2]. The kite moves away from the ground station during ground-gen, unwinding the tether from a drum, which turns a generator. The electrical energy from the generator is then transmitted to shortterm storage (e.g., battery or supercapacitor) and from there to the grid [5]. Once the kite has reached the maximum prescribed length of the tether, it is depowered and reeled back in, only to be instantly reeled out again, leading to a recurrent pumping cycle, which lasts a couple of minutes each (Figure 1). 


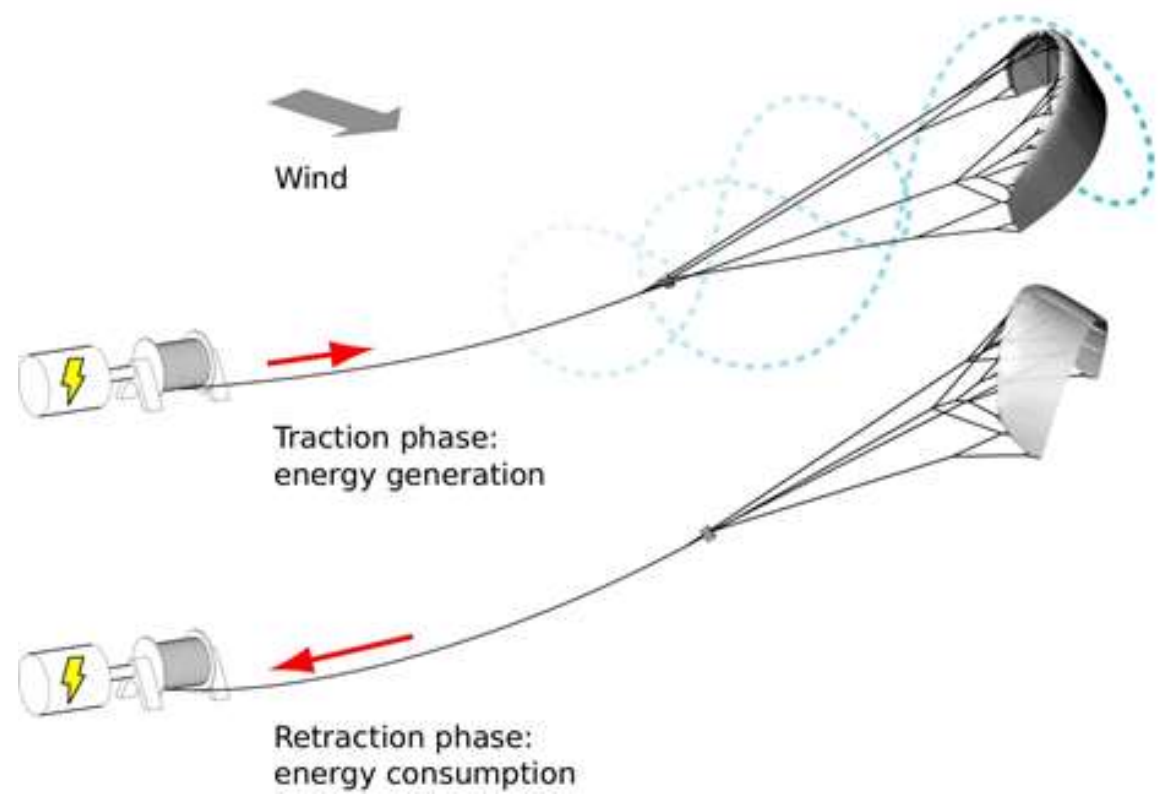

Figure 1. The pumping cycle of an airborne wind energy system consisting of a fixed ground station and a soft-wing kite flying crosswind manoeuvres [6].

The reel-in phase consumes less energy than is generated during the reel-out phase. In the reel-in phase, the crosswind manoeuvres are discontinued, and the kite is depowered, resulting in a positive net power outcome [4]. It is important to note that even when fully reeled in, the kite will still be around 200-250m away from the ground, which means the kite itself is not that perceptible when in operation, only during the initial launch and the final landing it is clearly visible. Regarding the kite systems, soft-wing kites consist of inflatable membrane wings and resemble kites used for paragliding or kite surfing [2] (see Figure 2). In contrast, fixed-wing kites look more like conventional aircraft or drones (see Figure 3). Hybrid-wing kites combine a rigid support structure with a textile membrane canopy. Concerning flight operation, during crosswind and tetheraligned operation, just the lift forces of the kite are transferred to the ground and converted there into electricity, whereas for the rotational operation of the entire kite, torque of the kite is transferred and converted at the ground [3]. During crosswind operation, the kite flies figures of eight or circles during the reel-out phase, increasing the amount of energy harvested [4]. The combination of a fixed ground station with crosswind operation is most common [4].

AWE systems are still in the development phase, with only a few systems in operation with launching customers. Testing of these prototypes and theoretical conceptualizations suggest that the emerging technology could have multiple benefits over conventional wind turbines. AWE systems can capture stronger and more constant winds at higher altitudes [7], and the harvesting operation could be continuously adjusted to available wind resources, which may both result in a higher potential energy yield for AWE systems than for wind turbines [8]. Besides, AWE systems require fewer materials, leading to a lower carbon footprint $[9,10]$. Existing and planned prototypes of AWE systems are easier to transport, install and uninstall than wind turbines. This means that one could use AWE systems in contexts that are not suitable for wind turbines, such as for mobile applications (e.g., festivals, construction sites), hurricane areas - where systems can be securely stored to avoid damage -, remote locations (e.g., islands, such as shown in Figure 2, communities, or mines), repowering old wind turbine platforms offshore, and floating offshore wind energy systems in deep waters [2,11-14]. In some of these contexts, AWE systems could potentially replace electricity produced by diesel generators with cheaper and renewable electricity $[11,12]$. However, AWE systems are more complex to 
realize technically than wind turbines [15]. Some technical challenges are not completely solved yet, such as continuous automated operation (including take-off, nominal operation, landing), long-term durability of system components, and operation under extreme weather conditions or landing in an emergency [16].

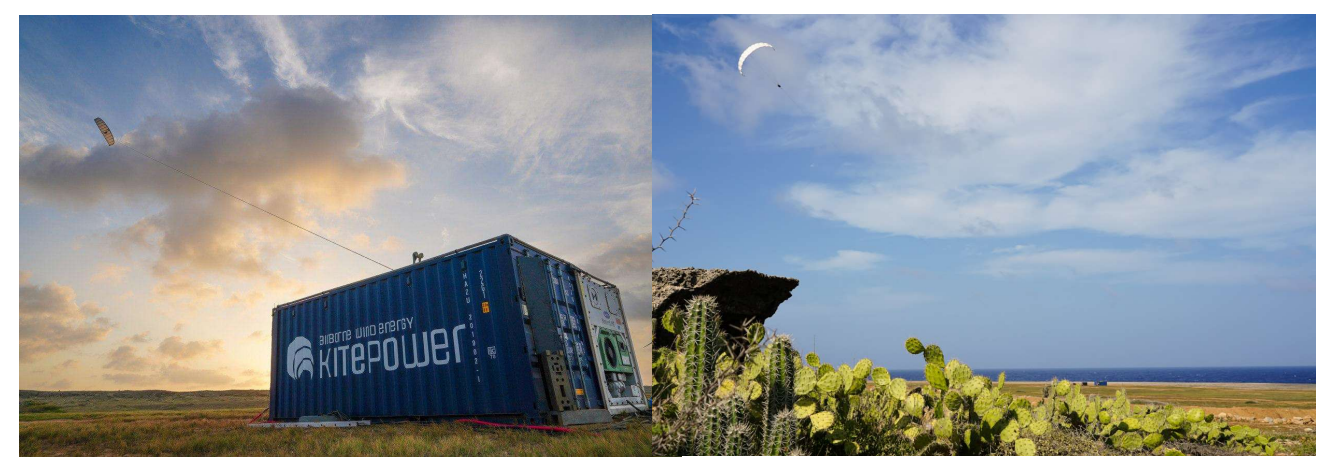

Figure 2. Pilot operation of the $100 \mathrm{~kW}$ AWE system of Kitepower on the Caribbean island Aruba in October 2021 (photo courtesy of Kitepower B.V.).

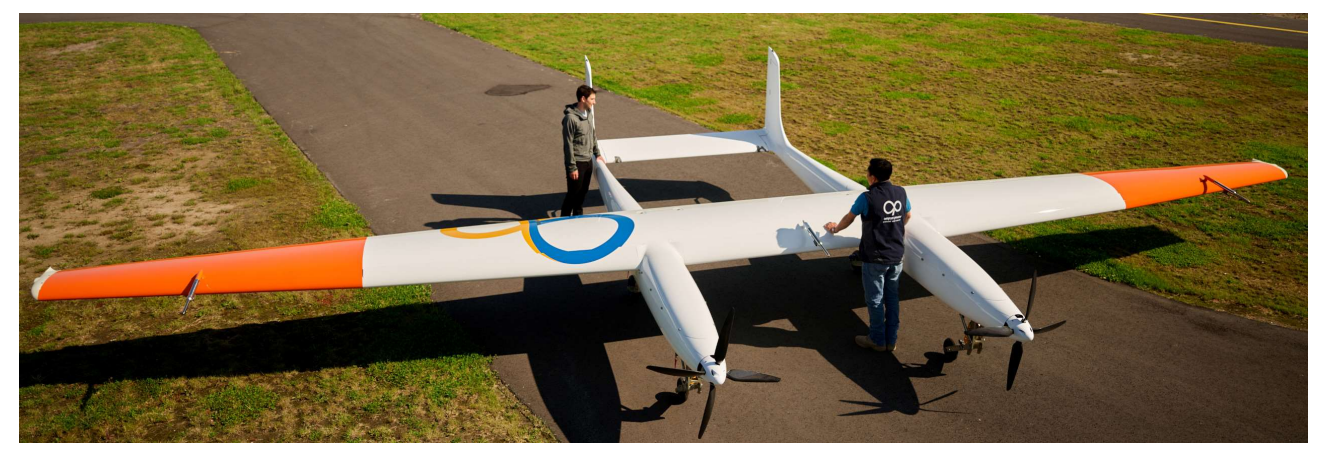

Figure 3. Ampyx Power's AP3 during flight testing on Breda International Airport in May 2021 (photo courtesy of Ampyx Power B.V.).

\subsection{How AWE Systems Interact with People and Nature and Why Research into Public Responses Is Relevant}

This paper examines the public's interaction with AWE from a psychological perspective. This is relevant because interactions between AWE systems, on the one side, and people and nature, on the other side, will shape public responses to the technology and could even delay or prevent a proposed infrastructure. Other low-carbon energy projects, including wind turbines, carbon capture and storage, biomass power plants, and geothermal and nuclear energy developments, have been hindered and cancelled in the past due to strong negative responses of the public [17-22].

Like conventional wind turbines, AWE systems will interact with people and nature when deployed. Direct interactions could relate to the technology's sound emissions, visibility, and ecological impacts, as indicated by research on wind turbines [18,23]. Potential acoustic impacts could result from noises emitted by the generator, winch, tether and the flying kite. The appearance of an AWE system, specifically the ground station, tether and kite, could lead to visual impacts. Due to the flying nature of the kites, ecological impacts would mainly concern the technology's influence on birds and bats. This is exacerbated by the fact that developers plan to initially deploy AWE systems in more remote and rural areas [16,24], where avian wildlife can be omnipresent. An additional human-technology interaction could relate to the perceived and actual safety 
of the kites. The uncontrolled crash of an AWE system could cause severe damage to people or property.

This paper uses the term public responses to refer to people's internal and external reactions to the technology. This includes cognitive and affective evaluations of AWE and behaviour directed at the implementation of the technology (e.g., protesting it, advocating for it). Cognitive evaluations are based on knowledge and beliefs, whereas affective evaluations are grounded in emotions. Public responses to energy technologies should be taken seriously, no matter how 'irrational' they appear to developers and authorities. Otherwise, resulting public opposition can lead to increased implementation costs, decreased political support for the energy technology in question, and ultimately limit the sector's scale and contribution to renewable energy targets [18]. Therefore, it is important to understand which aspects of AWE could shape public responses to the technology and how.

\subsection{Why Collaborations Between Engineers and Social Scientists are Needed for the} Success of AWE

In the AWE developer community, we have registered an optimism bias not just regarding the technological potential of the technology but also concerning public responses to it, as illustrated by the following quote: "High altitude wind power (HAWP) devices [AWE systems] can conceptually surpass CWTs [conventional wind technologies] due to higher production capacity, more acceptable electricity cost, 90\% less material consumption, higher societal and environmental acceptance because of lower visual and acoustic impacts and they operate well above the range of avian wildlife." [25] (p. 900).

On the one hand, optimism is needed for innovation because it positively influences creativity [26] and active problem solving [27]. "New technologies, new techniques, and new approaches to societal needs are not likely to happen unless someone somewhere believes in their merits strongly enough to persist and bring them to fruition." [28] (p. 27). On the other hand, being overly optimistic can also be a pitfall because it can obscure the reality and increase the risk of overlooking potential problems, especially regarding less tangible yet influential aspects of the technology like public responses to it. For example, developers and researchers in the field commonly assume that public responses will be more favourable for AWE systems than for wind turbines because of the supposedly lower visual, acoustic, and ecological impacts of AWE [25,29,30]. Yet, incorrect or simplified assumptions about public responses could lead to problems with the technology's deployment later on [31]. Therefore, collaborations between natural and social scientists would help get a more realistic perspective on how the public perceives the technology. Moreover, it would be especially beneficial to investigate public responses to AWE at an early stage of technology development to avoid that the public will reject technology implementation at a stage when large amounts of time and money have already been invested [32]. Findings from early public response research could then be considered in the further development and deployment of AWE to improve uptake of the technology.

\subsection{The Aim of This Paper and the Research Questions}

This literature review investigates what has been written about public responses to AWE so far and whether these perspectives tend to be overly optimistic. As a result, the review reveals what is not (empirically) known yet but should be known, leading to research recommendations. The aim of the paper results in the following three research questions:

1. What does the literature say about public responses to AWE?

2. To what extent are conclusions regarding public responses to AWE based on empirical evidence?

3. To what extent is there an optimism bias regarding public responses to AWE among researchers in the field of AWE? 
The following second section explains the terminology and research method adopted for this review. Section three describes and discusses results from the literature review and answers the research questions. Finally, section four concludes with a brief summary of the findings and provides recommendations for future research and practice.

\section{Research Method}

The language that researchers use is important because it influences the definition of the research problem as well as the approach to studying it [33]. The same terms can be interpreted differently across disciplines (e.g., attitude). Therefore, it is essential to clarify what the terms mean to understand and compare research findings. However, social scientific research on renewable energies has often failed to consider the importance of terminology.

\subsection{Why the Term Public Responses Should Be Used Instead of Social Acceptance or NIMBY}

Much research into public responses to energy technologies has adopted the term social acceptance. Although the concept has evolved over the years from describing simply a society-technology relationship to including the relationships and interests of different stakeholders, it remains contested for several reasons [18]. First, many authors interpret and use the concept differently depending on the discipline and context, which makes integrating research findings difficult and hinders understanding what social acceptance means empirically [34]. Second, by using social acceptance as a concept, many other potential attitudes and responses to renewable energies are ignored, including support, uncertainty, active resistance, indifference, or ignorance [35]. Of course, a given person or community may show no response to an energy infrastructure beyond mere acceptance, but whether that is the case has to be investigated and should not be assumed from the start [35]. Third, the concept maintains and potentially legitimates a normative top-down perspective on how people relate to the energy system [35]. That is, people are seen as having to accept externally proposed energy infrastructures. Yet, to successfully realize a sustainable energy transition, people need to change their attitudes and behaviour on many levels [31]. For example, they have to start using the new energy infrastructure, reduce their energy use, align it with renewable energy supplies, and approve of energy policies that stimulate behaviour change. People are more likely to make these changes when they actively support rather than passively accept energy projects [31]. Thus, a better understanding of public support and not just acceptance is needed. Fourth, social acceptance tends to draw all the attention to host communities and ignore the role of the developers or regulatory bodies [18]. Yet, the practices of developers and authorities, such as the way that information is shared and the public is involved, can strongly influence public responses to a project.

In public discourse and some scientific literature, objectors to energy projects are sometimes characterized as NIMBYs. The term Not-in-my-backyard implies that a community or an individual only opposes energy projects that would be sited in their direct proximity ("backyard") but not those located further away. Thus, they are seen as acting out of pure self-interest (i.e., do not think of the greater good), ignorance (i.e., do not understand the need for more renewable energy facilities), and irrationality (i.e., respond overly emotional) [36]. However, empirical evidence for the assumption that NIMBY explains negative attitudes to wind energy projects is lacking, and the term is too simplistic to capture the different concerns, perceptions, and motivations that can cause resistance [37,38]. Besides, labelling objectors as NIMBYs influences how project developers and authorities interact with the public and often leads them to tackle expected, yet inaccurate, motivations for opposition with ineffective measures [31]. For example, by offering financial compensation to address assumed selfishness or providing 'expert' information about the project to reduce supposed ignorance. Finally, NIMBY 
implies that opponents to wind energy and their views and concerns are not legitimate, which can be perceived as an offence and escalate the discourse further [36]. Thus, there is a strong consensus in the sciences now that NIMBY should no longer be used.

The term public responses has been suggested as an inclusive and non-normative concept for investigating the social dimension of energy technologies in a more accurate and nuanced way [35]. Therefore, this paper refers to interactions between AWE and individuals, groups, communities, and society by using the term public responses to AWE.

\subsection{Literature Search}

An initial scoping search of the AWE literature in May 2021 showed that public responses to AWE are not yet an established field of research. No publications were focusing predominantly on this topic. The small number of publications identified as relevant usually only contained a few sentences about public responses to AWE, and these publications used widely different terms to refer to the same topic. Therefore, it was necessary to search the full-text of publications, rather than just the title or abstract, for a range of different keywords to conduct an exhaustive literature review on public responses. We chose the database Google Scholar for the systematic identification of literature because it is the biggest, general full-text database [39]. Between August and September 2021, we searched Google Scholar by combining two sets of keywords with the operator AND. The first set contained synonyms of AWE, such as high altitude wind energy, kite power, and airborne wind turbine. The second set consisted of words that could be used to refer to public responses to AWE, including public acceptance, local support, and community concern (see Appendix 1 for the complete sets of keywords). We selected the keywords based on the initial scoping search, the fourth author's (i.e., RS) knowledge of the AWE literature, and published literature reviews on public responses to wind turbines that were either cited fairly often or were written by influential authors in the field [40-42]. Due to Google Scholar's limit of 256 characters per search, we had to conduct 60 separate searches to combine the two sets of keywords in all possible ways. We did not use any search filters (e.g., publication year) to ensure that we would not miss any relevant literature.

In addition to the Google Scholar searches, we published posts on LinkedIn [43] and in an AWE-focused research forum on ResearchGate [44] to identify any other relevant literature. Both posts received considerable attention; The LinkedIn post had over 4,000 views in the feed, 53 reactions, and 12 shares, and forum members read the ResearchGate post 55 times. Yet, neither led to the identification of relevant literature. After removing duplicates and non-scientific records (e.g., websites, brochures), 348 publications were left. In the last step of the literature search, we manually included four additional publications that we did not find through the Google Scholar searches but that the first author (i.e., HS) knew were relevant.

\subsubsection{Selection Process}

From the 352 identified records, we selected publications that met the following inclusion and exclusion criteria:

1. The publication is written in English;

2. It refers to aspects relating to public responses to AWE;

3. It is a full-text version of a peer-reviewed journal article, a peer-reviewed book chapter, a peer-reviewed conference paper, or a doctoral dissertation;

4. The part regarding public responses to AWE is the respective authors' contribution and not just a paraphrase of another source.

In general, a lot of AWE research is done in the context of doctoral dissertations, which is why we included this publication type in the review. See Figure 4 below for the detailed selection process. 


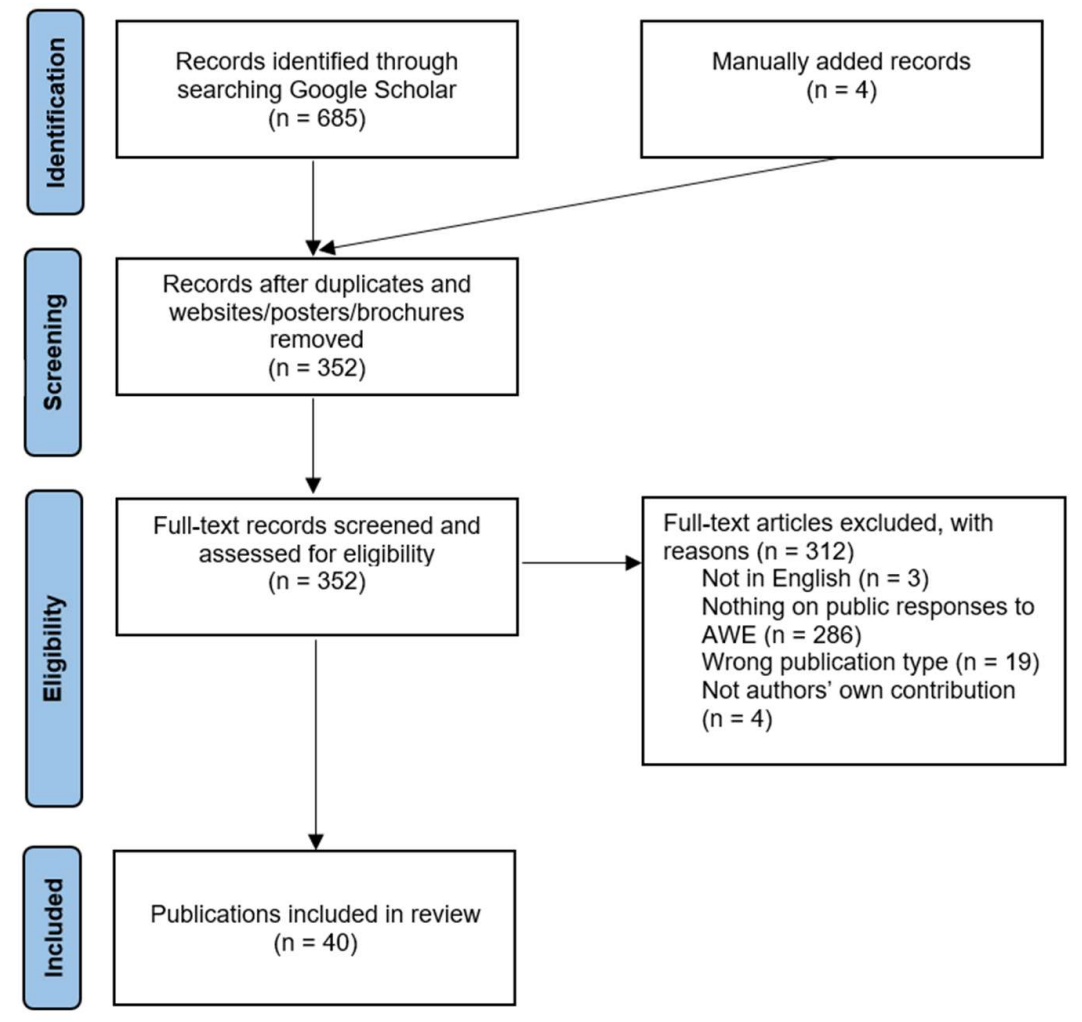

Figure 4. Flow diagram of the selection process for publications on public responses to airborne wind energy.

\subsubsection{Selected Literature}

After selection, a total of 40 publications remained to be reviewed in this study. See Appendix B for data on the authors, journal, publication type, and the year of publication. To validate the selection of literature, we conducted a topic search in Web of Science using the same AWE keywords as for this review. Web of Science is a database of indexed peerreviewed publication. The Web of Science search resulted in 420 records published between 1981 and 2021, with the majority being published between 2012 and 2021 . The publications we selected for this review were published between 2007 and 2021, with most being published after 2016. Public funding and interest in research on AWE increased significantly in 2015. For example, the doctoral training network AWESCO (Airborne Wind Energy System Modelling, Control and Optimisation) was launched in January 2015 funded by the European Union's Horizon 2020 research and innovation program [45]. Subsequently, the European Union funded an entire series of research and development projects that led to the significant advancement of AWE technology. In June 2015, Makani presented the M600, the biggest and most powerful AWE system until now, at the 6th international Airborne Wind Energy Conference (AWEC 2015) in Delft [46]. Makani was one of the leading AWE developers until its closure in 2020 [47]. The launch of AWESCO, Makani's presentation, and the follow-up funding are developments that likely contributed to the sudden surge in publications after 2015.

Taken together, the comparison with the Web of Science records on AWE suggests that the outcomes of our Google Scholar search are likely representative of the existing peer-reviewed AWE literature and that only a small number of all AWE publications discuss public responses to the technology. Those publications that do tend to have a 
technical and/or economic focus and only mention public responses to AWE in passing (34 out of 40 in this review).

\section{Results and Discussion}

The selected publications discuss five major aspects regarding public responses to AWE: safety and related aspects, visibility, sound emissions, ecological impact, and the siting of AWE systems. We will explain them below, starting with the most commonly mentioned ones.

\subsection{Safety and Related Aspects}

The reviewed literature assumes that the public might worry about the safety of AWE and that safety concerns could vary depending on the specific type of AWE system. For example, the public might perceive soft-wing kites as safer than fixed-wing or hybridwing kites due to the lighter materials [48]. However, in contrast to what the public might believe, an uncontrolled crash of a soft-wing kite could easily cause harm because of the impact of the mechatronic control unit that is suspended from the wing, or the wing itself, which is a large and heavy structure. Furthermore, apart from the kite system, the mode of electricity generation is expected to influence safety perceptions. For example, the use of fly-gen systems might raise concerns about electric tethers moving through the air [49]. Finally, the literature presumes that the public, especially pilots and regulators in the aviation industry, might see AWE systems as posing a risk to regular aviation [50].

In expectation of public safety concerns, there is a consensus in the field that the industry has to prove safe operation to gain favourable public responses $[5,15,51,52]$. Proofing reliable operations includes establishing safety regulations [53-55], having AWE systems with high fault tolerance [51,56], and minimizing the risk of accidents to an acceptable level [57]. Furthermore, the literature argues that to avoid public concerns, AWE systems should be located away from populated areas until the systems are proven to be safe $[24,58,59]$. AWE systems should also only operate in designated areas to prevent accidents with other aircraft $[59,60]$.

Conventional wind turbines can also pose risks to the public (e.g., ice throw resulting from ice build-up on the moving blades, and on rare occasions, blade throw, tower topple, or fire) [61]. However, these safety risks do not seem to influence public responses to wind turbines, or at least it is not discussed in the wind energy literature. The public might see the safety of AWE more critically because, in contrast to wind turbines, there is a lack of research on the risks of continuous, long-term operation of AWE systems as they have not been operated over extended periods yet. Moreover, a flying system might seem more hazardous than an entirely ground-based energy system.

\subsection{Visual Aspects}

While the literature expects safety concerns to harm people's responses to AWE, it often assumes that low visibility of AWE systems will reduce public concerns $[59,60]$. Some authors go as far as to claim that AWE systems "ensure unobstructed views of the local environment" [50] (p. 738). However, this depends on one's distance from the system because the ground station or base would be visible from close up.

In general, many authors agree that AWE systems are less noticeable than wind turbines, mainly due to the high altitude at which AWE systems operate $[29,30,50,53,62-$ 64]. Additional features of AWE systems that are said to contribute to a lower visual impact are the replacement of the tower with a relatively thin tether [57] and the reduction in shadow flicker [65]. Shadow flicker refers to the flickering effect that is caused when moving turbine blades or a kite periodically cast a shadow on the ground. Most AWE systems can be expected to produce only a weak and sporadic shadow flicker at a given location on the ground because the kite operates at higher altitudes and constantly changes its position during the pumping cycles. It is suggested to land the kite when there is little wind to further reduce the visual impact of AWE systems [52,64]. The reviewed 
literature claims that the low visibility of AWE systems makes them suitable for installations in ecologically sensitive areas or at tourist destinations [66].

For wind turbines, research has found that visual impacts and changes to the landscape strongly correlate with lower support for proposed projects and negative attitudes towards existing wind developments [23]. The effect of visual impacts on attitudes often depends on how disturbed people are by the wind turbines, resulting in a stronger correlation between visual impacts and negative attitudes when annoyance levels are higher. Given the research on wind turbines, it is essential to investigate how the public perceives the visibility of AWE and how that influences their attitudes and responses to the technology. Just because the AWE field judges the visibility of AWE as low, it does not mean that the public experiences low visual impacts. There might be other optical features of AWE systems (e.g., the colours, the flight pattern and fast movements of the kite) that people could perceive as disturbing. Besides, as with wind turbines, when people are generally annoyed by the technology, it might also influence the extent to which they experience the visibility of AWE systems negatively.

\subsection{Acoustic Aspects}

Similar to the visibility of AWE systems, the sound emissions are also commonly expected to be lower than for wind turbines [24,25,57,59,66-69]. The lower sound emissions of AWE are typically explained by the high altitude at which AWE systems operate $[50,53,65]$ and are assumed to make AWE systems more suitable for installations in ecologically sensitive areas or at tourist destinations [66]. For ground-gen systems, the generator is one of the system elements causing the most noise, so it has been suggested to make the ground station soundproof to reduce sound emissions further [57].

A few authors directly conclude that the lower sound emissions of AWE compared to wind turbines would positively influence public responses $[25,59,60]$. However, there is some evidence that audible noise from wind turbines can lead to annoyance in people, particularly when sound pressure levels exceed $40 \mathrm{~dB}(\mathrm{~A})$ [70]. Annoyance, in turn, may be related to self-reported health complaints like sleep disturbance. Therefore, soundbased setback distances are sometimes applied to reduce annoyance caused by wind turbine noise. However, annoyance with wind turbines and associated health complaints are also linked to subjective factors, such as attitudes towards wind turbines and evaluation of visual impacts, and may hence remain despite noise limits [70]. The same might be true for AWE. Multiple developers reported that the sound emissions of their AWE systems comply with local noise limits (Hanna, 2020; Omexom, 2020b). However, the public might still feel disturbed, especially when sound pressure levels are above $40 \mathrm{~dB}(\mathrm{~A})$.

\subsection{Ecological Aspects}

AWE's most prominent ecological effects are considered collisions with birds and bats (see Figure 5) and disturbance of mammals and avian wildlife [73]. Regarding impacts on birds, the literature often assumes that an AWE system would cause fewer bird strikes than a wind turbine $[25,50,59,60,65,68]$. A recurring argument is that the kite operates above the range of avian wildlife except for the short take-off and landing phases. However, the tether can also pose a risk to birds because it moves at a higher speed than them and is therefore difficult to anticipate for birds [73]. 


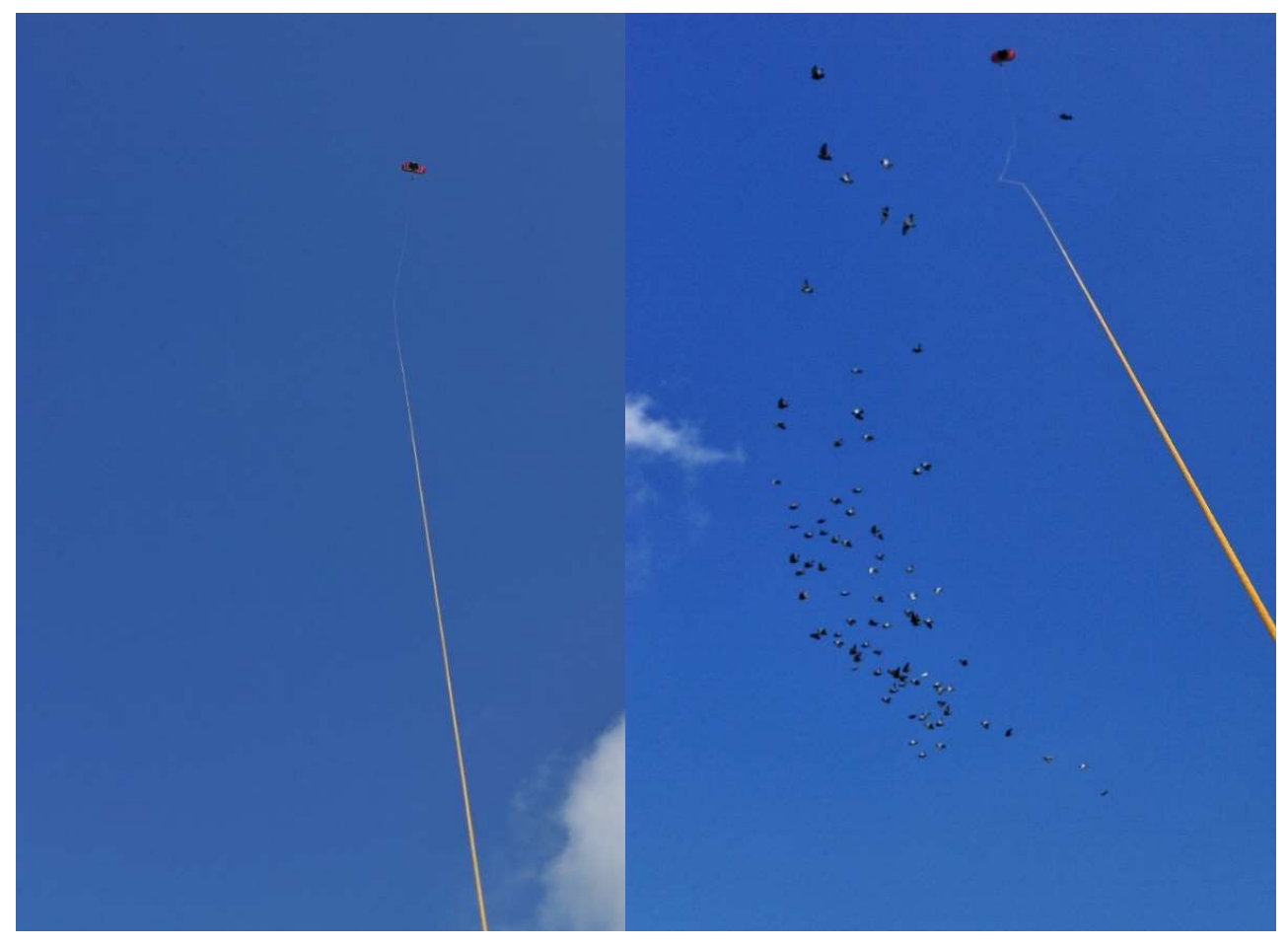

Figure 5. Pilot operation of the $20 \mathrm{~kW}$ kite power system of TU Delft [72] before (left) and after a bird collided with the tether (right). The photos were taken on 28 June 2011 at Valkenburg airfield, The Netherlands, by Max Dereta.

The only peer-reviewed study on the ecological impact of AWE suggests that between two and thirteen birds would collide with the kite and around eleven would come into contact with the tether per year, resulting in an annual total of thirteen to twenty-four bird fatalities [71]. ${ }^{1}$ These estimates fall within the range of bird fatalities that have been recorded for wind turbines (0.6 to 63 fatalities per year, with a median of 7). The study considered the number of bat strikes for AWE to be negligible [71]. The results are not based on field data of AWE but rather on comparisons with bird mortality statistics for glider aircraft and power lines and should therefore be interpreted with caution.

AWE developers commissioned a few (non-peer-reviewed) reports to receive permits for (continued) prototype testing, which contain actual field data on the ecological impact of AWE (e.g., surveys of bat/bird flight and breeding activity). Two of these reports directly observed how an operating AWE system affects local bird or bat populations $[75,76]$. All assessments concluded that the impact of the AWE system on local avian wildlife is negligible [71,75,77]. However, that does not mean that AWE, in general, is harmless to birds and bats, as some engineers claim [29,30]. Results from an environmental impact assessment at one test site are only transferrable to other test sites to a limited extent because of wildly varying environmental conditions $[73,75,76]$. Therefore, more longitudinal empirical research is needed across different ecosystems because the occurrence and types of species differ across habitats, time of day, and seasons (e.g., breeding season, migratory season) [71,73]. Moreover, birds' habitat use and flight

1 : The estimates are based on predictions for year-round 24/7-operation of Ampyx Power's planned 2MW fixed-wing kite, with a tether length of $1 \mathrm{~km}$ and an operating altitude of $200-450 \mathrm{~m}$. The bird activity level at the site was assumed to be "moderate". 
behaviour changes in the different phases of the year and weather conditions (e.g., little wind vs strong wind). Knowing how a given AWE system or test site affects birds is essential for mitigating measures that counteract potential adverse effects. Mitigation measures could range from changes to the design of AWE systems [78] to regulations that apply to the construction, operation, and maintenance of AWE sites. The latter could, for example, include establishing disturbance buffer zones for sensitive species during the breeding season and constant monitoring and regular inspection of site and equipment [71,77].

Taken together, the claim that AWE systems cause fewer bird strikes than wind turbines is not sufficiently backed up with empirical data yet. Besides, it is unknown how AWE's perceived or actual ecological impacts would shape public responses. Evidence on the influence of ecological concerns on public responses to wind turbines is somewhat mixed [23], so it would be interesting to investigate how wildlife concerns shape the public's view on AWE.

\subsection{Siting of AWE Systems}

The literature assumes that siting decisions influence public responses to the technology and vice versa. First, public attitudes are expected to affect the selection of AWE sites and the density of systems in one location [64,79]. For wind turbines, there is research on how different spatial characteristics of wind developments (e.g., distance to dwellings, number of turbines (visible), size of turbines, clustering of turbines) influence attitudes towards a specific wind facility or wind energy in general [23]. However, the research has been inconsistent. Further studies are needed, especially to control for confounding variables (e.g., local economic benefits) and examine cumulative effects (i.e., the interactive effect of multiple spatial characteristics on attitudes). Next to the attributes of wind projects, the impact of landscape aesthetics on public responses has been investigated. There is initial evidence that public support is higher for wind turbines placed in landscapes of low rather than high aesthetic quality $[80,81]$.

Second, the AWE literature assumes that public responses would be more favourable for offshore deployment because visual and acoustic impacts are thought to be less disturbing to the public than onshore [52,82-84]. While there is some evidence that the public prefers offshore wind turbines, preferences depend on additional factors, such as distance to the coast and potential offshore wind sites [85]. Offshore wind development has been related to some of the same topics of discussion as onshore development (e.g., visual and acoustic impacts, economic or employment benefits, procedural justice concerns, climate change mitigation) [42]. However, offshore wind farms also raise different issues, partially because offshore wind farms affect other stakeholders (e.g., beach users, owners of coastal tourism companies) [36,42]. For example, potential negative or positive impacts on tourism, marine wildlife, the fishing industry, and the recreational activity sector (i.e., boating, yachting, surfing, fishing) are often discussed $[42,86,87]$. It should be noted that the AWE industry is planning to develop floating offshore plants, which have less of an impact on marine wildlife $[11,83,88]$. Therefore, it remains to be seen whether public responses differ between on- and offshore AWE developments and, if so, why.

Finally, as mentioned before, potential public safety concerns also play a role in siting decisions (e.g., flying in unpopulated areas and restricted airspace). Taken together, it seems that the influence of siting decisions on public responses is heavily intertwined with the visual, ecological, acoustic, and safety aspects of the technology.

\subsection{Summary of the Findings from the Literature Review}

The first aim of this review was to identify what the literature says about public responses to AWE. In short, we found that the literature commonly assumes that the safety, visibility, sound emissions, ecological impacts, and the siting of AWE shape public responses to the technology. 
The literature agrees that public safety concerns (e.g., regarding fixed-wing kites, flygen) could harm people's responses to AWE. The consensus is that to foster a positive public image, the reliability and safety of AWE would have to be demonstrated by establishing safety regulations in the industry, increasing the fault tolerance of systems, minimizing accident risks, and operating away from populated areas.

The visibility of AWE is believed to be lower than that of wind turbines because of the higher operational altitude, the absence of a tower, reduced shadow flicker, and the possibility to retrieve the kite in low wind conditions. Therefore, the low expected visibility is assumed to influence public responses positively. However, evidence on wind turbines shows that low visibility does not necessarily relate to a more positive public view, especially if people are generally annoyed with the technology.

Sound emissions of AWE as heard on the ground are also often believed to be lower than for wind turbines due to the higher operational altitude. The low acoustic impacts are thought to have a positive influence on public responses. For wind turbines, evidence for a relationship between lower acoustic impacts and higher support is mixed, partly because attitudes towards wind turbines in general and evaluations of visual impacts have been found to moderate the influence of acoustic impacts on public responses.

Due to the high operational altitude of AWE, many authors presume that AWE systems would strike significantly fewer birds and bats than wind turbines and that this lower ecological impact would influence public responses favourably. However, current evidence on AWE's ecological impact is conflicting and more research is needed across sites, weather conditions, time of day, and seasons. Even if ecological impacts were understood better, it is still unclear how they would affect public responses to AWE. Evidence for the influence of wildlife concerns on attitudes towards wind turbines is rather mixed.

Finally, public responses to AWE and siting decisions are expected to influence each other. For example, public safety concerns might trigger the industry to operate outside of densely populated regions and the public might respond more favourably to the technology if it is placed in certain areas rather than others (e.g., offshore instead of onshore)

The second aim of this paper was to assess to what extent conclusions regarding public responses to AWE are based on empirical evidence. Except for the ecological approximation study, none of the selected publications supported their claims about public responses with empirical evidence. Conclusions about which factors influence public responses to AWE and how were almost exclusively based on authors' opinions and maybe even on their hopes regarding the acceptability and success of the technology. Some of the statements seemed exaggerated, especially given the lack of scientific proof (e.g., AWE "will not be audible", allows "unobstructed views of the local environment", and is "bird and bat-safe", leading to "higher societal and environmental acceptance" than wind turbines) $[25,29,50,66]$.

The third aim of this review was to investigate to what extent there is an optimism bias regarding public responses to AWE among developers and researchers in the field. In general, the field seems to expect that the public will process information about AWE (e.g., costs and benefits) in an entirely rational manner. In contrast, existing research has shown that subjective factors, such as political orientation and emotional reactions to energy technologies, affect which information people seek about energy-related topics and how they evaluate it [88-90]. Thus, the assumption that information processing will occur without any motivational biases appears to have led to an overly optimistic perspective on public responses to AWE. In particular, the literature is very optimistic about how people will perceive AWE's visual, acoustic, and ecological impacts, which has led some authors to confidently conclude that the public would prefer AWE over wind turbines. Yet, some authors also recognize that AWE could trigger social resistance [82,83] and that understanding public responses is, therefore, key for the deployment of the technology [52,91-93]. It has even been suggested that the commercialization of AWE depends on creating a positive public vision of the technology [94]. More specifically, if 
the public and key stakeholders negatively perceive AWE (e.g., due to worries about lacking reliability and safety), it could reduce support for and investment in the technology and hinder its large-scale deployment. Although some acknowledge that the public's view on AWE is crucial for the success of the technology, one study found that concerns about public responses are still much less common in the field than other concerns, such as lacking regulations and economic viability [16]. This was especially the case among public and academic stakeholders, although they were also underrepresented in the study compared to business stakeholders, which may have distorted the findings.

\section{Conclusions and Recommendations}

Airborne wind energy (AWE) is an emerging renewable energy technology that harvests higher-altitude winds (300-600m above the ground) with automatically controlled kites. Like other renewables, AWE will interact with people and nature. These interactions will shape public responses to the technology and influence its large-scale deployment. If stakeholders ignore people's concerns about the technology and the public starts showing resistance to AWE, it could increase implementation costs, decrease political support for AWE, and minimize AWE's contribution to meeting renewable energy targets [18]. Therefore, it is essential to understand which aspects of the technology and its deployment (e.g., visibility, safety, sound emissions, ecological impacts, project planning processes) will impact public responses and how. This literature review assessed what is already known about public responses to AWE and where there are knowledge gaps.

We can draw two main conclusions from the literature review. First, there is a lack of empirical research on public responses to AWE. Only a small number of AWE publications discusses how the technology might interact with people and nature. The vast majority of these publications are authored by engineers (83\% of authors) and none of the papers are written from a social scientific perspective. As a result, claims about how the technology will influence public views are only based on authors' assumptions and not on scientific evidence, such as interviews, surveys, or experiments. Second, most researchers in the field seem to be rather optimistic about how the public will perceive the emerging technology. Specifically, authors estimate AWE's visual, acoustic, and ecological impacts to be low, which they assume will lead to favourable public responses to the technology $[24,25,29,30,50,53,59,60,62-69]$. It is undisputed that the optimism of the engineers is needed to realize such technically challenging innovations as AWE. However, an overly positive view on how the public will perceive the technology could lead developers and authorities to overlook potential social issues and thereby hinder the deployment of AWE [31].

\subsection{Research Recommendations}

Emerging research on public responses to AWE should learn from the large body of literature on the acceptability of other low-carbon energy technologies. By drawing on wind energy acceptance research, a number of research recommendations and considerations for AWE can be specified, which we discuss in the following.

\subsubsection{Acceptance Is not the Default}

Following from the assumption that there is widespread public support for wind energy, it is often concluded that opposition to wind energy must be deviant or illegitimate $[36,95]$. This bias often leads to superficial assessments of public responses to wind energy. Specifically, separating supporters and objectors into two different categories is overly simplistic and of little use because both supporters and objectors can hold varying views and are motivated by many reasons [95]. Sometimes the same issue is used by both sides but then interpreted differently to support their respective position (e.g., globally, the environment benefits from more wind energy vs the local environment might be harmed by wind turbines). The assumption that opposition is less legitimate 
than support gives rise to and is maintained by the view that resistance stems from ignorance or lacking knowledge and that it can be eliminated by providing knowledge or creating understanding [95]. Yet, it could be that opponents simply disagree with aspects of wind energy rather than that they are uninformed. Furthermore, it should not be expected that resistance towards suggested wind energy facilities will diminish after construction because this also implies that initial opposition is misplaced or irrelevant $[95,96]$. In fact, it is normal that there is some opposition to proposed wind projects and negative attitudes towards existing wind facilities, and it is not any different for other big developments, such as transmission lines and landfills [23].

Taken together, the industry and other stakeholders must realize that for the longterm success of AWE, they need to understand public perceptions and responses fully and - as such - go beyond overcoming potential public resistance. If the sole intention of engaging with the public is to reduce opposition, such engagement can backfire because it hinders meaningful understanding of the public [23,97]. "So long as [research] presumes that opposition is misinformed, ignorant or deviant it can never fully understand individual or community experiences with wind power. Moreover, by presuming that opposition needs to be avoided or overcome it fails to acknowledge the potential value of objectors' points of view" [95] (p.1840). Opposition and acceptance, and any other response in between, are likely motivated by different concerns and needs. Thus, rather than expecting that everyone should or will eventually be accepting of AWE and wind energy, in general, researchers and other stakeholders should equally consider all potential responses by the public to understand the bigger picture [36].

\subsubsection{Public Responses Are Contextual and Dynamic}

When studying public responses to AWE, it is critical to consider the broader social, cultural, and environmental context because public acceptability of energy technologies is not just determined by individual perceptions $[18,198]$. Instead of only focusing on individuals' beliefs, values and attitudes regarding AWE, it should be taken into account how situational factors like policy contexts, the characteristics and local meanings of deployment sites, communities, and cultures, and the project planning process shape public responses [99]. In addition, research should consider how other key stakeholders, such as developers, policy makers, and the media, understand the implementation of AWE and, specifically, how their interactions with the public influence responses to the technology [100]. Because "public responses are not developed in a vacuum or in the abstract, but rather in interaction with others that have an interest in a development particularly those that are advocating and promoting it" [99] (p. 4).

Furthermore, public responses to energy technologies and the acceptability of specific projects change over time and should, therefore, be understood as a dynamic process $[99,100]$. However, most energy research has studied community responses during the consenting process and there is a lack of longitudinal studies, which has prevented a deeper understanding of project acceptability [18]. Therefore, research on AWE should focus on the dynamics of the relationships between communities and wind energy projects and use acquired insights from longitudinal studies to improve public engagement practices.

\subsubsection{Diverse Research Methods Should be Employed}

A range of different research methods should be applied to capture the likely complex and multifactorial nature of public responses to AWE. At the beginning of wind energy acceptance research in the 1990s, researchers commonly used opinion polls to assess public perceptions of wind energy. However, opinion polls have been increasingly criticized for looking at isolated opinions without considering the wider social and institutional context [18]. Yet, there are ways to make quantitative research more contextual, for example, by including survey items that tap into socially constructed influences, such as community relationships and norms (e.g., perceived social pressure to oppose or accept a proposed project) [101]. Nonetheless, quantitative data is limited 
because it often fails to reflect the variety of attitudes and perceptions across and within individuals. Qualitative interviews, as well as more innovative and novel data collection methods, such as Q-methodology, discourse analysis, ethnography, diaries, life-history interviews and social media analysis, could complement quantitative survey research by providing additional insights into people's socially constructed responses to AWE $[101,102]$.

When assessing public responses to emerging energy technologies like AWE, research should consider that most people are likely unaware of and have little knowledge of the technology they are asked to comment [32,103]. This means that their attitudes and opinions will probably change over time as they learn more about the technology and thereby differ from what was originally measured. Thus, researchers should carefully consider how they can avoid measuring only so-called "non-attitudes". One solution could be to provide balanced information on the technology through techniques, such as information-choice questionnaires or focus groups [32,103].

\subsubsection{A Comprehensive Theoretical Framework is Needed}

Most social scientific research on public responses to wind energy lacks an explanatory theoretical framework to generate hypotheses and explain findings [34,37]. As a result, most literature only describes perceptions of wind farms but cannot explain them properly, which is especially problematic when findings are inconsistent across studies [37]. Furthermore, it is hard to draw any conclusions about the implications of research when it is unknown what causes the underlying psychological processes [37]. While multiple researchers have attempted to converge the broader factors that influence public acceptability into one framework [e.g., 101,102], these frameworks do not completely reflect the complexity of the matter and have not been widely adopted [18]. It would be worthwhile for future research to build a comprehensive, interdisciplinary model of energy acceptability that helps to map and better understand the complex influences that form public perceptions of and responses to AWE and wind energy projects in general.

\subsection{Recommendations for Practice}

The implementation of low-carbon technologies has often been seen as benefiting the regional or (inter)national public (e.g., mitigating climate change) while disproportionately burdening local populations (e.g., impacting local landscapes) $[23,105]$. It is becoming increasingly common to offer benefits to host communities, such as creating local jobs, rental payments to landowners, community ownership models, lower local electricity prices, and landscape and ecological enhancement measures to balance out local negative impacts [18]. Also AWE systems will affect place and people at deployment sites, and compensation measures will, therefore, likely be considered for the deployment of AWE. However, developers should be aware that the provision of community benefits does not automatically increase project support. A recent review concluded that compensation schemes for renewable energy projects, among others, are more likely to be acceptable and not perceived as bribery and thus facilitate project support when the compensations fit with local needs and concerns [106]. Thus, developers should identify who the relevant community is (e.g., individuals living close to the proposed infrastructure vs individuals negatively affected by the project), their needs and concerns, and what type of compensation would best match those.

Compensation alone is usually not that effective and should therefore be combined with wider public engagement strategies, especially by making decision-making processes fairer for the public and increasing trust in responsible developers and authorities $[23,106]$. For trust to be meaningful in planning processes, it should not simply be utilized to reduce opposition [95]. Instead, the trust should also be extended to acknowledging that the public has valid views and knowledge and that open participation can lead to positive results independent of whether these support a given project proposal. As a result, the public might sometimes deem a given project proposal 
inappropriate or unacceptable, but that would help create a dialogue between developers, planners, local communities, and scientists and thereby lead to opportunities for improving future developments of AWE.

In conclusion, how AWE's characteristics (e.g., visibility, sound emissions) influence public responses will likely depend on a range of situational (e.g., policy context, characteristics of landscape) and psychological factors (e.g., the public's trust in project developers, perceived fairness of decision making). Collaborative efforts of engineers and social scientists and lessons learnt from research on other renewable energies can facilitate a more successful implementation of AWE in the future.

Author Contributions: Conceptualization, H.S., G.d.V., R.J.R. and R.S.; methodology, H.S., G.d.V., R.J.R. and R.S.; investigation, H.S.; writing-original draft preparation, H.S.; writing-review and editing, H.S., G.d.V., R.J.R. and R.S.; visualization, H.S. and R.S.; supervision, G.d.V., R.J.R. and R.S.; project administration, H.S. and R.S.; funding acquisition, R.S. and R.J.R. All authors have read and agreed to the published version of the manuscript.

Funding: This publication is part of the project New Energy and Mobility Outlook for the Netherlands (NEON) with project number 17628 which is jointly financed by the Dutch Research Council (NWO), Ampyx Power B.V., and Kitepower B.V. The APC was funded by TU Delft.

Acknowledgments: We would like to acknowledge SkySails Power $\mathrm{GmbH}$ and Omexom Renewable Energies Offshore $\mathrm{GmbH}$ for providing us with extracts from the ecological impact assessment and sound emissions studies on the pilot plant SkyPower100.

Conflicts of Interest: The funders had no role in the design of the study; in the collection, analyses, or interpretation of data; in the writing of the manuscript, or in the decision to publish the results. 


\section{Appendix A}

Table A1. Keywords selected for the literature search in Google Scholar.

Airborne wind energy keyword set (individual keywords were combined with operator OR)
Public responses and attitudes keyword set (individual keywords were combined with operator OR)
Included in Google

Scholar search "airborne wind energy", "airborne wind power", "high altitude wind energy", "high altitude wind power", "crosswind kite", "kite model", "kite wind generator", "kite wind energy", "airborne wind turbine", "flying electric generator", "kite power", "kite energy", "pumping kite", "lighter-than-air wind energy system", "kite-based wind energy", "kite wind power", "kite-powered system", (parawing AND energy), ("wind power" AND "flying kite"), (kite AND "tracking control"), (kite AND "flight control"), "kite generator", (laddermill AND kite), ("kite system" AND "power generating"), ("power kite" AND "wind energy"), ("tethered airfoil" AND "wind energy"), ("kite system" AND wind), ("kite system" and "wind energy") "social acceptance", "societal acceptance", "environmental acceptance", "public acceptance", "acceptance by the public", "accepted by the public", "accepted by people", "social acceptability", "public acceptability", "environmental acceptability", "socially accepted", "publicly accepted", "social support", "public support", "community support", "local support", "social perception", "public perception", "public opinion", "public attitude", "public involvement", "community involvement", "public participation", "community participation", "community engagement", "social impact", "public resistance", "public opposition", "community concern", "societal impact", "social dimension", "NIMBY", "not in my backyard", "visual impact", "visual intrusion", "visual disturbance", "visual effect", "auditory impact", "auditory intrusion", "auditory disturbance", "auditory effect", "acoustic impact", "acoustic intrusion", "acoustic disturbance", "acoustic effect", "noise impact", "noise intrusion", "noise disturbance", "noise effect", "ecological impact" 
Excluded from

Google Scholar

search because key-

words did not yield

any results in com-

bination with key-

words from the

other set "community acceptance", "local acceptance", "acceptance by the people", "acceptance by the community", "acceptance by locals", "accepted by the community", "accepted by locals", "societal acceptability", "community acceptability", "local acceptability", "acceptability by the public", "acceptability by people", "acceptability by the community", "acceptability by locals", "support by the public", "support by the community", "support by locals", "socially supported", "locally supported", "social resistance", "community resistance", "social opposition", "community opposition", "positive perception", "negative perception", "perception by people", "perception by the community", "perception by locals", "public preference", "social preference", "concerns by the community", "public engagement", "social implication"

\section{Appendix B}

Table A2. Publication details of the papers selected for the review on public responses to AWE.

\begin{tabular}{|c|c|c|c|c|c|c|}
\hline Author(s) & Year & Title & $\begin{array}{l}\text { Publica- } \\
\text { tion type }\end{array}$ & $\begin{array}{l}\text { Publication me- } \\
\text { dium }\end{array}$ & $\begin{array}{l}\text { Professional } \\
\text { background au- } \\
\text { thor(s) }\end{array}$ & $\begin{array}{l}\text { Identifica- } \\
\text { tion }\end{array}$ \\
\hline $\begin{array}{l}\text { Abbate \& Sara- } \\
\text { ceno }\end{array}$ & 2019 & $\begin{array}{l}\text { What else is emerging } \\
\text { from the horizon? }\end{array}$ & $\begin{array}{l}\text { Book } \\
\text { chapter }\end{array}$ & $\begin{array}{l}\text { Lecture Notes in En- } \\
\text { ergy }\end{array}$ & $\begin{array}{l}1 \text { physicist, } 1 \text { en- } \\
\text { gineer }\end{array}$ & $\begin{array}{l}\text { Google } \\
\text { Scholar }\end{array}$ \\
\hline $\begin{array}{l}\text { Ahmed, Hably } \\
\text { \& Bacha }\end{array}$ & 2012 & $\begin{array}{l}\text { High altitude wind } \\
\text { power systems: A survey } \\
\text { on } \\
\text { flexible power kites }\end{array}$ & $\begin{array}{l}\text { Confer- } \\
\text { ence pa- } \\
\text { per }\end{array}$ & $\begin{array}{l}\text { In } 2012 \text { XXth Inter- } \\
\text { national Conference } \\
\text { on Electrical } \\
\text { Machines }\end{array}$ & 3 engineers & $\begin{array}{l}\text { Google } \\
\text { Scholar }\end{array}$ \\
\hline $\begin{array}{l}\text { Alonso-Pardo \& } \\
\text { Sanchez-Ar- } \\
\text { ringa }\end{array}$ & 2015 & $\begin{array}{l}\text { Kite model with bridle } \\
\text { control for wind-power } \\
\text { generation }\end{array}$ & $\begin{array}{l}\text { Journal } \\
\text { article }\end{array}$ & Journal of Aircraft & 2 engineers & $\begin{array}{l}\text { Google } \\
\text { Scholar }\end{array}$ \\
\hline $\begin{array}{l}\text { Archer, Delle } \\
\text { Monache, \& Rife }\end{array}$ & 2014 & $\begin{array}{l}\text { Airborne wind energy: } \\
\text { Optimal locations and } \\
\text { variability }\end{array}$ & $\begin{array}{l}\text { Journal } \\
\text { article }\end{array}$ & Renewable Energy & $\begin{array}{l}1 \text { engineer, } 2 \text { at- } \\
\text { mospheric scien- } \\
\text { tists }\end{array}$ & Manually \\
\hline Bauer & 2018 & $\begin{array}{l}\text { Multidisciplinary Opti- } \\
\text { mization of Drag Power } \\
\text { Kites }\end{array}$ & $\begin{array}{l}\text { Doctoral } \\
\text { disserta- } \\
\text { tion }\end{array}$ & $\begin{array}{l}\text { Technical Univer- } \\
\text { sity of Munich re- } \\
\text { pository }\end{array}$ & 1 engineer & $\begin{array}{l}\text { Google } \\
\text { Scholar }\end{array}$ \\
\hline $\begin{array}{l}\text { Bosch, Schmehl, } \\
\text { Tiso, } \\
\text { \& Rixen }\end{array}$ & 2014 & $\begin{array}{l}\text { Dynamic nonlinear aeroe- } \\
\text { lastic model of a kite for } \\
\text { power generation }\end{array}$ & $\begin{array}{l}\text { Journal } \\
\text { article }\end{array}$ & $\begin{array}{l}\text { Journal of Guidance, } \\
\text { Control, and Dy- } \\
\text { namics, }\end{array}$ & 4 engineers & $\begin{array}{l}\text { Google } \\
\text { Scholar }\end{array}$ \\
\hline Bronstein & 2011 & $\begin{array}{l}\text { Harnessing rivers of } \\
\text { wind: A technology and }\end{array}$ & $\begin{array}{l}\text { Journal } \\
\text { article }\end{array}$ & $\begin{array}{l}\text { Technological Fore- } \\
\text { casting \& Social } \\
\text { Change }\end{array}$ & $\begin{array}{l}1 \text { public policy } \\
\text { major }\end{array}$ & Manually \\
\hline
\end{tabular}


policy assessment of altitude wind power in the

U.S.

Bruinzeel, Klop, 2018 Ecological impact of air-

Brenninkmeijer borne wind energy tech\& Bosch nology: current state of

$\begin{array}{lllll}\text { Book } & \text { In R. Schmehl (Ed.) } & 3 \text { ecologists, } & 1 & \text { Google } \\ \text { chapter } & \begin{array}{l}\text { Airborne } \quad \text { Wind } \\ \text { innovation } \\ \text { Energy }\end{array} & \begin{array}{l}\text { Scholar } \\ \text { management }\end{array} & \\ & & & \end{array}$
search agenda

\begin{tabular}{|c|c|c|c|c|c|c|}
\hline $\begin{array}{l}\text { Cahoon } \\
\text { Harmon }\end{array}$ & 2008 & $\begin{array}{l}\text { Airborne wind energy: } \\
\text { Implementation and } \\
\text { design } \\
\text { for the us air force }\end{array}$ & $\begin{array}{l}\text { Conferen } \\
\text { ce paper }\end{array}$ & $\begin{array}{l}\text { In 9th Annual } \\
\text { International } \\
\text { Energy Conversion } \\
\text { Engineering } \\
\text { Conference }\end{array}$ & 2 engineers & $\begin{array}{l}\text { Google } \\
\text { Scholar }\end{array}$ \\
\hline Cherubini & 2017 & $\begin{array}{l}\text { Advances in airborne } \\
\text { wind energy and wind } \\
\text { drones }\end{array}$ & $\begin{array}{l}\text { Doctoral } \\
\text { dissertati } \\
\text { on }\end{array}$ & $\begin{array}{l}\text { University } \\
\text { Sant'Anna School of } \\
\text { Advanced Studies } \\
\text { repository }\end{array}$ & 1 engineer & \\
\hline $\begin{array}{l}\text { Cherubini, } \\
\text { Moretti } \\
\text { Fontana }\end{array}$ & 2018 & $\begin{array}{l}\text { Dynamic modeling of } \\
\text { floating offshore airborne } \\
\text { wind energy converters }\end{array}$ & $\begin{array}{l}\text { Book } \\
\text { chapter }\end{array}$ & $\begin{array}{l}\text { In R. Schmehl (Ed.) } \\
\text { Airborne Wind } \\
\text { Energy }\end{array}$ & 3 engineers & $\begin{array}{l}\text { Google } \\
\text { Scholar }\end{array}$ \\
\hline $\begin{array}{l}\text { Cherubini, } \\
\text { Vertechy } \\
\text { Fontana }\end{array}$ & 2016 & $\begin{array}{l}\text { Simplified model of } \\
\text { offshore airborne wind } \\
\text { energy converters }\end{array}$ & $\begin{array}{l}\text { Journal } \\
\text { article }\end{array}$ & Renewable Energy & 3 engineers & $\begin{array}{l}\text { Google } \\
\text { Scholar }\end{array}$ \\
\hline $\begin{array}{l}\text { Chihaia, } \\
\text { Nicolaie, } \\
\text { Cîrciumaru, El- } \\
\text { Leathey, \& } \\
\text { Constantin }\end{array}$ & 2019 & $\begin{array}{l}\text { Market Potential Of } \\
\text { Unconventional Wind } \\
\text { Turbines. A Technology } \\
\text { Review }\end{array}$ & $\begin{array}{l}\text { Conferen } \\
\text { ce paper }\end{array}$ & $\begin{array}{l}\text { Proceedings of } 2019 \\
\text { International } \\
\text { Conference on } \\
\text { Hydraulics and } \\
\text { Pneumatics } \\
\end{array}$ & 5 engineers & $\begin{array}{l}\text { Google } \\
\text { Scholar }\end{array}$ \\
\hline De Lellis & 2016 & $\begin{array}{l}\text { Airborne wind energy } \\
\text { with tethered wings: } \\
\text { Modeling, analysis and } \\
\text { control }\end{array}$ & $\begin{array}{l}\text { Doctoral } \\
\text { dissertati } \\
\text { on }\end{array}$ & $\begin{array}{l}\text { Universidade } \\
\text { Federal de Santa } \\
\text { Catarina repository }\end{array}$ & 1 engineer & $\begin{array}{l}\text { Google } \\
\text { Scholar }\end{array}$ \\
\hline $\begin{array}{l}\text { De Lellis, } \\
\text { Mendonça, } \\
\text { Saraiva, Trofino, } \\
\text { \& Lezana }\end{array}$ & 2016 & $\begin{array}{l}\text { Electric power generation } \\
\text { in wind farms with } \\
\text { pumping kites: An } \\
\text { economical analysis }\end{array}$ & $\begin{array}{l}\text { Journal } \\
\text { article }\end{array}$ & Renewable Energy & 5 engineers & $\begin{array}{l}\text { Google } \\
\text { Scholar }\end{array}$ \\
\hline $\begin{array}{l}\text { Fagiano } \\
\text { Milanese }\end{array}$ & 2012 & $\begin{array}{l}\text { Airborne wind energy: an } \\
\text { overview }\end{array}$ & $\begin{array}{l}\text { Conferen } \\
\text { ce paper }\end{array}$ & $\begin{array}{l}\text { In } 2012 \text { American } \\
\text { Control Conference }\end{array}$ & 2 engineers & $\begin{array}{l}\text { Google } \\
\text { Scholar }\end{array}$ \\
\hline $\begin{array}{l}\text { Fagiano, } \\
\text { Milanese \& Piga }\end{array}$ & 2010 & $\begin{array}{l}\text { High-altitude wind } \\
\text { power generation }\end{array}$ & $\begin{array}{l}\text { Journal } \\
\text { article }\end{array}$ & $\begin{array}{lr}\text { IEEE } & \text { Transactions } \\
\text { on } & \text { Energy } \\
\text { Conversion } & \\
\end{array}$ & 3 engineers & $\begin{array}{l}\text { Google } \\
\text { Scholar }\end{array}$ \\
\hline $\begin{array}{l}\text { Girrbach, Hol, } \\
\text { Bellusci \& Diehl }\end{array}$ & 2017 & $\begin{array}{l}\text { Towards robust sensor } \\
\text { fusion for state estimation } \\
\text { in airborne applications } \\
\text { using GNSS and IMU }\end{array}$ & $\begin{array}{l}\text { Journal } \\
\text { article }\end{array}$ & $\begin{array}{l}\text { IFAC- } \\
\text { PapersOnLine }\end{array}$ & 4 engineers & $\begin{array}{l}\text { Google } \\
\text { Scholar }\end{array}$ \\
\hline $\begin{array}{l}\text { Gulabani, } \\
\text { Karim, } \\
\text { Radhakrishnan, } \\
\text { Shenoy, \& Zuber }\end{array}$ & 2020 & $\begin{array}{lr}\text { Review } & \text { on } \\
\text { Unconventional Wind } \\
\text { Energy }\end{array}$ & $\begin{array}{l}\text { Journal } \\
\text { article }\end{array}$ & $\begin{array}{l}\text { Journal } \\
\text { Engineering } \\
\text { Technological } \\
\text { Sciences }\end{array}$ & $\begin{array}{l}1 \text { engineer, } 4 \\
\text { unknown }\end{array}$ & $\begin{array}{l}\text { Google } \\
\text { Scholar }\end{array}$ \\
\hline
\end{tabular}




\begin{tabular}{|c|c|c|c|c|c|c|}
\hline Jehle \& Schmehl & 2014 & $\begin{array}{l}\text { Applied tracking control } \\
\text { for kite power systems }\end{array}$ & $\begin{array}{l}\text { Journal } \\
\text { article }\end{array}$ & $\begin{array}{l}\text { Journal of Guidance, } \\
\text { Control, and } \\
\text { Dynamics }\end{array}$ & 2 engineers & $\begin{array}{l}\text { Google } \\
\text { Scholar }\end{array}$ \\
\hline $\begin{array}{l}\text { Kamp, Ortt \& } \\
\text { Doe }\end{array}$ & 2018 & $\begin{array}{l}\text { Niche strategies to } \\
\text { introduce kite-based } \\
\text { airborne wind energy }\end{array}$ & $\begin{array}{l}\text { Book } \\
\text { chapter }\end{array}$ & $\begin{array}{l}\text { In R. Schmehl (Ed.) } \\
\text { Airborne wind } \\
\text { energy }\end{array}$ & $\begin{array}{ll}1 \text { engineer, } & 1 \\
\text { economist, } & 1 \\
\text { innovation } & \\
\text { studies major } & \end{array}$ & $\begin{array}{l}\text { Google } \\
\text { Scholar }\end{array}$ \\
\hline $\begin{array}{l}\text { Key de Souza } \\
\text { Mendonça, } \\
\text { Braga, \& Bornia }\end{array}$ & 2020 & $\begin{array}{l}\text { Airborne Wind Energy } \\
\text { Systems: Current state } \\
\text { and } \\
\text { challenges to reach the } \\
\text { market }\end{array}$ & $\begin{array}{l}\text { Conferen } \\
\text { ce paper }\end{array}$ & $\begin{array}{lr}\text { International Joint } \\
\text { Conference } & \text { on } \\
\text { Industrial } & \\
\text { Engineering } & \text { and } \\
\text { Operations } & \\
\text { Management } & \\
\end{array}$ & 3 engineers & $\begin{array}{l}\text { Google } \\
\text { Scholar }\end{array}$ \\
\hline Khan \& Rehan & 2016 & $\begin{array}{l}\text { Harnessing airborne } \\
\text { wind energy: Prospects } \\
\text { and challenges }\end{array}$ & $\begin{array}{l}\text { Journal } \\
\text { article }\end{array}$ & $\begin{array}{l}\text { Journal of Control, } \\
\text { Automation and } \\
\text { Electrical } \\
\text { Systems }\end{array}$ & 2 engineers & $\begin{array}{l}\text { Google } \\
\text { Scholar }\end{array}$ \\
\hline Luetsch & 2011 & $\begin{array}{l}\text { High Altitude Wind } \\
\text { Power Plants: Dealing } \\
\text { with the risks }\end{array}$ & $\begin{array}{l}\text { Conferen } \\
\text { ce paper }\end{array}$ & $\begin{array}{l}\text { 11th AIAA Aviation } \\
\text { Technology, } \\
\text { Integration, and } \\
\text { Operations (ATIO) } \\
\text { Conference }\end{array}$ & 1 manager & $\begin{array}{l}\text { Google } \\
\text { Scholar }\end{array}$ \\
\hline $\begin{array}{l}\text { Lunney, Ban, } \\
\text { Duic, \& Foley }\end{array}$ & 2017 & $\begin{array}{l}\text { A state-of-the-art review } \\
\text { and feasibility analysis of } \\
\text { high altitude wind power } \\
\text { in Northern Ireland }\end{array}$ & $\begin{array}{l}\text { Journal } \\
\text { article }\end{array}$ & $\begin{array}{lr}\text { Renewable } & \text { and } \\
\text { Sustainable } & \text { Energy } \\
\text { Reviews } & \end{array}$ & 4 engineers & $\begin{array}{l}\text { Google } \\
\text { Scholar }\end{array}$ \\
\hline Malz & 2020 & $\begin{array}{l}\text { Airborne Wind Energy- } \\
\text { to fly or not to fly? }\end{array}$ & $\begin{array}{l}\text { Doctoral } \\
\text { dissertati } \\
\text { on }\end{array}$ & $\begin{array}{l}\text { Chalmers } \\
\text { University } \\
\text { Technology } \\
\text { repository }\end{array}$ & 1 engineer & $\begin{array}{l}\text { Google } \\
\text { Scholar }\end{array}$ \\
\hline $\begin{array}{l}\text { Malz, Walter, } \\
\text { Göransson, \& } \\
\text { Gros }\end{array}$ & 2021 & $\begin{array}{l}\text { The value of airborne } \\
\text { wind energy to the } \\
\text { electricity system }\end{array}$ & $\begin{array}{l}\text { Journal } \\
\text { article }\end{array}$ & Wind Energy & 4 engineers & $\begin{array}{l}\text { Google } \\
\text { Scholar }\end{array}$ \\
\hline $\begin{array}{l}\text { Paulig, Bungart } \\
\text { \& Specht }\end{array}$ & 2013 & $\begin{array}{lr}\text { Conceptual design of } \\
\text { textile kites } & \text { considering } \\
\text { overall } & \text { system } \\
\text { performance } & \end{array}$ & $\begin{array}{l}\text { Book } \\
\text { chapter }\end{array}$ & $\begin{array}{l}\text { In U. Ahrens, M. } \\
\text { Diehl \& R. Schmehl } \\
\text { (Ed.) Airborne wind } \\
\text { energy }\end{array}$ & 3 engineers & $\begin{array}{l}\text { Google } \\
\text { Scholar }\end{array}$ \\
\hline $\begin{array}{l}\text { Piancasatelli \& } \\
\text { Cassani }\end{array}$ & 2020 & $\begin{array}{l}\text { Energy transfer from } \\
\text { airborne high altitude } \\
\text { turbines: Part III. } \\
\text { Performance evaluation } \\
\text { of small, mass-produced, } \\
\text { fixed wing generators }\end{array}$ & $\begin{array}{l}\text { Journal } \\
\text { article }\end{array}$ & $\begin{array}{l}\text { Journal of } \\
\text { Engineering and } \\
\text { Applied Sciences }\end{array}$ & 2 engineers & $\begin{array}{l}\text { Google } \\
\text { Scholar }\end{array}$ \\
\hline $\begin{array}{l}\text { Ranneberg, } \\
\text { Wölfle, } \\
\text { Bormann, } \\
\text { Rohde, Breipohl, } \\
\& \\
\text { Bastigkeit }\end{array}$ & 2018 & $\begin{array}{l}\text { Fast power curve and } \\
\text { yield estimation of } \\
\text { pumping } \\
\text { airborne wind energy } \\
\text { systems }\end{array}$ & $\begin{array}{l}\text { Book } \\
\text { chapter }\end{array}$ & $\begin{array}{l}\text { In R. Schmehl (Ed.) } \\
\text { Airborne wind } \\
\text { energy }\end{array}$ & $\begin{array}{l}1 \\
\text { mathematician, } \\
2 \text { engineers, } 1 \\
\text { architect/design } \\
\text { er, } 1 \\
\text { meteorologist, } 1 \\
\text { unknown }\end{array}$ & $\begin{array}{l}\text { Google } \\
\text { Scholar }\end{array}$ \\
\hline
\end{tabular}




\begin{tabular}{|c|c|c|c|c|c|c|}
\hline Roberts & 2018 & $\begin{array}{l}\text { Quad-rotorcraft to } \\
\text { harness high-altitude } \\
\text { wind energy }\end{array}$ & $\begin{array}{l}\text { Book } \\
\text { chapter }\end{array}$ & $\begin{array}{l}\text { In R. Schmehl (Ed.) } \\
\text { Airborne } \quad \text { wind } \\
\text { energy }\end{array}$ & 1 engineer & Manually \\
\hline $\begin{array}{l}\text { Roberts, } \\
\text { Shepard, } \\
\text { Caldeira, } \\
\text { Cannon, Eccles, } \\
\text { Grenier } \quad \& \\
\text { Freidin }\end{array}$ & 2007 & $\begin{array}{l}\text { Harnessing high-altitude } \\
\text { wind power }\end{array}$ & $\begin{array}{l}\text { Journal } \\
\text { article }\end{array}$ & $\begin{array}{lr}\text { IEEE Transactions } \\
\text { on } \\
\text { Conversion }\end{array}$ & $\begin{array}{l}6 \text { engineers, } \\
\text { atmospheric } \\
\text { scientist }\end{array}$ & $\begin{array}{l}\text { Google } \\
\text { Scholar }\end{array}$ \\
\hline $\begin{array}{l}\text { Salma } \quad \& \\
\text { Schmehl }\end{array}$ & 2020 & $\begin{array}{l}\text { Flight anomaly detection } \\
\text { for airborne wind energy } \\
\text { systems }\end{array}$ & $\begin{array}{l}\text { Conferen } \\
\text { ce paper }\end{array}$ & $\begin{array}{l}\text { Journal of Physics: } \\
\text { Conference Series }\end{array}$ & 2 engineers & $\begin{array}{l}\text { Google } \\
\text { Scholar }\end{array}$ \\
\hline $\begin{array}{l}\text { Salma, Friedl \& } \\
\text { Schmehl }\end{array}$ & 2020 & $\begin{array}{l}\text { Improving reliability and } \\
\text { safety of airborne } \\
\text { wind energy systems }\end{array}$ & $\begin{array}{l}\text { Journal } \\
\text { article }\end{array}$ & Wind Energy & 3 engineers & $\begin{array}{l}\text { Google } \\
\text { Scholar }\end{array}$ \\
\hline $\begin{array}{l}\text { Salma, } \\
\text { Ruiterkamp, } \\
\text { Kruijff, van } \\
\text { Paassen } \quad \& \\
\text { Schmehl } \\
\end{array}$ & 2018 & $\begin{array}{l}\text { Current and expected } \\
\text { airspace regulations for } \\
\text { airborne wind energy } \\
\text { system }\end{array}$ & $\begin{array}{l}\text { Book } \\
\text { chapter }\end{array}$ & $\begin{array}{l}\text { In R. Schmehl (Ed.) } \\
\text { Airborne } \quad \text { wind } \\
\text { energy }\end{array}$ & 5 engineers & $\begin{array}{l}\text { Google } \\
\text { Scholar }\end{array}$ \\
\hline Sommerfeld & 2020 & $\begin{array}{l}\text { Optimal performance of } \\
\text { airborne wind energy } \\
\text { systems subject to } \\
\text { realistic wind profiles }\end{array}$ & $\begin{array}{l}\text { Doctoral } \\
\text { dissertati } \\
\text { on }\end{array}$ & $\begin{array}{l}\text { University of } \\
\text { Victoria repository }\end{array}$ & 1 engineer & $\begin{array}{l}\text { Google } \\
\text { Scholar }\end{array}$ \\
\hline Tulloch & 2021 & $\begin{array}{l}\text { Modelling and analysis of } \\
\text { rotary airborne wind } \\
\text { energy systems - a tensile } \\
\text { rotary power } \\
\text { transmission design }\end{array}$ & $\begin{array}{l}\text { Doctoral } \\
\text { dissertati } \\
\text { on }\end{array}$ & $\begin{array}{l}\text { University of } \\
\text { Strathclyde } \\
\text { Glasgow }\end{array}$ & 1 engineer & Manually \\
\hline Watson et al. & 2019 & $\begin{array}{l}\text { Future emerging } \\
\text { technologies in the wind } \\
\text { power sector: A European } \\
\text { perspective }\end{array}$ & $\begin{array}{l}\text { Journal } \\
\text { article }\end{array}$ & $\begin{array}{lr}\text { Renewable } & \text { and } \\
\text { Sustainable } & \text { Energy } \\
\text { Reviews } & \end{array}$ & 5 engineers & $\begin{array}{l}\text { Google } \\
\text { Scholar }\end{array}$ \\
\hline $\begin{array}{l}\text { Yan, Yee, \& } \\
\text { Huang }\end{array}$ & 2017 & $\begin{array}{l}\text { Preliminary research on } \\
\text { modelling and control of } \\
\text { two line kites for power } \\
\text { generation }\end{array}$ & $\begin{array}{l}\text { Conferen } \\
\text { ce paper }\end{array}$ & $\begin{array}{l}20174 \text { th Asia-Pacific } \\
\text { World Congress on } \\
\text { Computer } \\
\text { Science and } \\
\text { Engineering (APWC } \\
\text { on CSE) }\end{array}$ & 3 engineers & $\begin{array}{l}\text { Google } \\
\text { Scholar }\end{array}$ \\
\hline $\begin{array}{l}\text { Ye, Chaer, } \\
\text { Lawner, \& Ross }\end{array}$ & 2020 & $\begin{array}{l}\text { Viability of airborne wind } \\
\text { energy in the United } \\
\text { Kingdom }\end{array}$ & $\begin{array}{l}\text { Journal } \\
\text { article }\end{array}$ & $\begin{array}{l}\text { Journal of Thermal } \\
\text { Science and } \\
\text { Engineering } \\
\text { Applications }\end{array}$ & 4 engineers & $\begin{array}{l}\text { Google } \\
\text { Scholar }\end{array}$ \\
\hline Total & $\begin{array}{l}2007- \\
2021\end{array}$ & - & $\begin{array}{l}18 \\
\text { journal } \\
\text { articles; } 9 \\
\text { conferenc } \\
\text { e papers; } \\
8 \text { book } \\
\text { chapters; } \\
6 \\
\text { doctoral }\end{array}$ & - & $\begin{array}{l}\text { Engineering: } \\
\text { 100, atmospheric } \\
\text { science: } \\
\text { ecology: } \\
\text { physics: } \\
\text { innovation } \\
\text { studies: } \\
\text { mathematics: 1, } \\
\text { design/architect } \\
\text { ure: 1, public }\end{array}$ & $\begin{array}{l}\text { Google } \\
\text { Scholar: } 38, \\
\text { manually: } 4\end{array}$ \\
\hline
\end{tabular}


dissertati

ons policy

management: 1 ,

economy: 1 ,

management: 1 ,

unknown: 5

a The professional background of the authors of each paper was included in the count, so some authors that contributed to more than one paper were included multiple times. The Watson et al. paper discussed various technologies, so only the authors who wrote the part on AWE were included here.

\section{References}

1. Zillmann, U.; Bechtle, P. Emergence and Economic Dimension of Airborne Wind Energy. In Airborne Wind Energy. Green Energy and Technology; Schmehl, R., Ed.; Springer, Singapore, 2018; pp. 1-25, ISBN 978-981-10-1947-0.

2. Cherubini, A.; Papini, A.; Vertechy, R.; Fontana, M. Airborne Wind Energy Systems: A Review of the Technologies. Renew. Sust. Energ. Rev. 2015, 51, 1461-1476, doi:10.1016/J.RSER.2015.07.053.

3. Schmehl, R. Airborne Wind Energy - An Introduction to an Emerging Technology. Available online: http://awesco.eu/aweexplained/ (accessed on 8 July 2021).

4. Vermillion, C.; Cobb, M.; Fagiano, L.; Leuthold, R.; Diehl, M.; Smith, R.S.; Wood, T.A.; Rapp, S.; Schmehl, R.; Olinger, D.; et al. Electricity in the Air: Insights from Two Decades of Advanced Control Research and Experimental Flight Testing of Airborne Wind Energy Systems. Annu. Rev. Control 2021, doi:10.1016/J.ARCONTROL.2021.03.002.

5. Salma, V.; Friedl, F.; Schmehl, R. Improving Reliability and Safety of Airborne Wind Energy Systems. Wind Energy 2019, 23, 340-356, doi:10.1002/WE.2433.

6. Folkersma, M.; Schmehl, R.; Viré, A. Boundary Layer Transition Modeling on Leading Edge Inflatable Kite Airfoils. Wind Energy 2019, 22, 908-921, doi:10.1002/WE.2329.

7. Archer, C.L.; Caldeira, K. Global Assessment of High-Altitude Wind Power. Energies, 2009, 2, 307-319, doi:10.3390/EN20200307.

8. Bechtle, P.; Schelbergen, M.; Schmehl, R.; Zillmann, U.; Watson, S. Airborne Wind Energy Resource Analysis. Renew. Energ. 2019, 141, 1103-1116, doi:10.1016/J.RENENE.2019.03.118.

9. van Hagen, L. Life Cycle Assessment of Multi-Megawatt Airborne Wind Energy. Master Thesis, Technology University of Delft, The Netherlands, 8 July 2021. http://resolver.tudelft.nl/uuid:472a961d-1815-41f2-81b0-0c6245361efb (accessed on 26 October 2021).

10. Wilhelm, S. Life Cycle Assessment of Electricity Production from Airborne Wind Energy. In Airborne Wind Energy. Green Energy and Technology; Schmehl, R., Ed.; Springer: Singapore, 2018; pp. 727-750, ISBN 978-981-10-1947-0.

11. Ampyx Power. Products and Markets. Available online: https://www.ampyxpower.com/future/products-and-markets/ (accessed on 26 July 2021).

12. Kitepower. Market. Available online: https://thekitepower.com/markets/ (accessed on 26 July 2021).

13. Luchsinger, R.; Aregger, D.; Bezard, F.; Costa, D.; Galliot, C.; Gohl, F.; Heilmann, J.; Hesse, H.; Houle, C.; Wood, T.A.; et al. Pumping Cycle Kite Power with Twings. In Airborne Wind Energy. Green Energy and Technology; Schmehl, R., Ed.; Springer: Singapore, 2018; pp. 603-621, ISBN 978-981-10-1947-0.

14. IRENA. Offshore Renewables: An Action Agenda for Deployment, 2021. https://www.irena.org/publications/2021/Jul/Offshore-Renewables-An-Action-Agenda-for-Deployment (accessed on 26 October 2021).

15. Salma, V.; Schmehl, R. Flight Anomaly Detection for Airborne Wind Energy Systems. In Journal of Physics: Conference Series, Online, 28 September-2 October 2020.

16. ECORYS. Study on Challenges in the Commercialisation of Airborne Wind Energy Systems; 2018. European Commission. https://op.europa.eu/en/publication-detail/-/publication/a874f843-c137-11e8-9893-01aa75ed71a1/language-en (accessed on 26 October 2021).

17. Brunsting, S.; de Best-Waldhober, M.; Feenstra, C.F.J.; Mikunda, T. Stakeholder Participation Practices and Onshore CCS: Lessons from the Dutch CCS Case Barendrecht. Energy Procedia 2010, 4, 6376-6383, doi:10.1016/j.egypro.2011.02.655.

18. Ellis, G.; Ferraro, G. The Social Acceptance of Wind Energy: Where We Stand and the Path Ahead; 2016. European Commission. doi:10.2789/696070.

19. Uechi, J.; Murayama, T.; Nishikizawa, S. An Analysis of Factors Influencing Community Acceptance on Geothermal Power Development - the Cases of Yanaizu-Nishiyama and Oguni Geothermal Power Plants. In Papers on Environmental Information Science 2013, 283-288, doi:10.11492/ceispapers.ceis27.0_283.

20. Upreti, B.R.; van der Horst, D. National Renewable Energy Policy and Local Opposition in the UK: The Failed Development of a Biomass Electricity Plant. Biomass and Bioenergy 2004, 26, 61-69, doi:10.1016/S0961-9534(03)00099-0. 
21. Wang, F.; Gu, J.; Wu, J. Perspective Taking, Energy Policy Involvement, and Public Acceptance of Nuclear Energy: Evidence from China. Energy Policy 2020, 145, doi:10.1016/j.enpol.2020.111716.

22. Dütschke, E. What Drives Local Public Acceptance-Comparing Two Cases from Germany. Energy Procedia 2010, 4, 62346240, doi:10.1016/j.egypro.2011.02.636.

23. Rand, J.; Hoen, B. Thirty Years of North American Wind Energy Acceptance Research: What Have We Learned? Energy Res. Soc. Sci. 2017, 29, 135-148, doi:10.1016/j.erss.2017.05.019.

24. Piancastelli, L.; Cassani, S. Energy Transfer from Airborne High Altitude Turbines: Part III. Performance Evaluation of Small, Mass-Produced, Fixed Wing Generators. ARPN J. Eng. Appl. Sci. 2020, 15, 1355-1365. ISSN 1819-6608.

25. Lunney, E.; Ban, M.; Duic, N.; Foley, A. A State-of-the-Art Review and Feasibility Analysis of High Altitude Wind Power in Northern Ireland. Renew. Sust. Energ. Rev. 2017, 68, 899-911, doi:10.1016/J.RSER.2016.08.014.

26. Rego, A.; Sousa, F.; Marques, C.; Cunha, M.P. e. Optimism Predicting Employees' Creativity: The Mediating Role of Positive Affect and the Positivity Ratio. Eur. J. Work. Organ. Psychol. 2012, 21, 244-270, doi:10.1080/1359432X.2010.550679.

27. Nes, L.S.; Segerstrom, S.C. Dispositional Optimism and Coping: A Meta-Analytic Review. Pers. Soc. Psychol. Rev. 2016, 10, 235-251, doi:10.1207/S15327957PSPR1003_3.

28. Johnson, A.T. Innovation Is Tied to Optimism. IEEE Pulse 2021, 12, 27-29, doi:10.1109/MPULS.2021.3078601.

29. Cahoon, T.L.; Harmon, F.G. Airborne Wind Energy: Implementation and Design for the U.S. Air Force. In Proceedings of the 9th Annual International Energy Conversion Engineering Conference, San Diego: CA, 31 July-3 August 2011.

30. Ye, Z.; Chaer, I.; Lawner, H.; Ross, M. Viability of Airborne Wind Energy in the United Kingdom. J. Therm. Sci. Eng. Appl. 2020, 12, 011008-1-011008-11, doi:10.1115/1.4043387.

31. Perlaviciute, G.; Schuitema, G.; Devine-Wright, P.; Ram, B. At the Heart of a Sustainable Energy Transition: The Public Acceptability of Energy Projects. IEEE Power and Energy Mag. 2018, 16, 49-55, doi:10.1109/MPE.2017.2759918.

32. de Best-Waldhober, M.; Daamen, D.; Faaij, A. Informed and Uninformed Public Opinions on CO2 Capture and Storage Technologies in the Netherlands. Int. J. Greenh. Gas Control 2009, 3, 322-332, doi:10.1016/j.ijggc.2008.09.001.

33. Haggett, C. Social Acceptance and Interdisciplinarity: Understanding the Constructive Power of Terminology. In A Critical Approach to the Social Acceptance of Renewable Energy Infrastructures; Batel, S., Rudolph, D., Eds.; Palgrave Macmillan: Cham, Switzerland, 2021; pp. 123-139. ISBN 978-3-030-73699-6.

34. Busse, M.; Siebert, R. Acceptance Studies in the Field of Land Use - A Critical and Systematic Review to Advance the Conceptualization of Acceptance and Acceptability. Land Use Policy 2018, 76, 235-245, doi:10.1016/j.landusepol.2018.05.016.

35. Batel, S.; Devine-Wright, P.; Tangeland, T. Social Acceptance of Low Carbon Energy and Associated Infrastructures: A Critical Discussion. Energy Policy 2013, 58, 1-5, doi:10.1016/j.enpol.2013.03.018.

36. Wolsink, M. Wind power: Basic challenge concerning social acceptance. In Renewable Energy Systems; Kaltschmitt, M., Themelis, N.J., Bronicki, L.Y., Söder, L., Vega, L.A., Eds.; Springer: New York, USA, 2013; pp. 1785-1822 ISBN 1221812254.

37. Devine-Wright, P. Beyond NIMBYism: Towards an Integrated Framework for Understanding Public Perceptions of Wind Energy. Wind Energy 2005, 8, 125-139, doi:10.1002/we.124.

38. Wolsink, M. Invalid Theory Impedes Our Understanding: A Critique on the Persistence of the Language of NIMBY. Trans. Inst. Br. Geogr. 2006, 31, 85-91. doi:10.1111/j.1475-5661.2006.00191.x.

39. Gusenbauer, M. Google Scholar to Overshadow Them All? Comparing the Sizes of 12 Academic Search Engines and Bibliographic Databases. Scientometrics 2018, 118, 177-214, doi:10.1007/S11192-018-2958-5.

40. Enevoldsen, P.; Sovacool, B.K. Examining the Social Acceptance of Wind Energy: Practical Guidelines for Onshore Wind Project Development in France. Renew. Sust. Energ. Rev. 2016, 53, 178-184, doi:10.1016/J.RSER.2015.08.041.

41. Langer, K.; Decker, T.; Roosen, J.; Menrad, K. A Qualitative Analysis to Understand the Acceptance of Wind Energy in Bavaria. Renew. Sust. Energ. Rev. 2016, 64, 248-259, doi:10.1016/J.RSER.2016.05.084.

42. Wiersma, B.; Devine-Wright, P. Public Engagement with Offshore Renewable Energy: A Critical Review. Wiley Interdiscip. Rev. Clim. Change 2014, 5, 493-507, doi:10.1002/WCC.282.

43. Schmidt, H. I Am Working on My \#PhD on Public Responses to and Perceptions of \#airborne \#wind \#energy. Available online: https://www.linkedin.com/posts/helenasophiaschmidt_phd-airborne-wind-activity-6843810633151000576-8_dc (accessed on 25 October 2021).

44. Schmidt, H. Publications Mentioning Social Impact of AWE Needed. Available online: https://www.researchgate.net/project/AWESCO-Airborne-Wind-Energy-System-Modelling-Control-andOptimisation/update/6141f5e5d248c650eda43cd6 (accessed on 25 October 2021).

45. Schmehl, R. Summary. Available online: http://awesco.eu/summary/ (accessed on 21 October 2021).

46. Vander Lind, D. Developing a 600 KW Airborne Wind Turbine. In Proceedings of the Airborne Wind Energy Conference (AWEC 2015), Delft, The Netherlands, 15-16 June 2015; pp. 14-17.

47. Weiss, P. After Highflyer Crashes, Airborne Wind Energy Regroups. Engineering 2021, 7, 277-279, doi:10.1016/J.ENG.2021.01.004.

48. Paulig, X.; Bungart, M.; Specht, B. Conceptual Design of Textile Kites Considering Overall System Performance. In Airborne Wind Energy. Green Energy and Technology; Ahrens, U., Diehl, M., Schmehl, R., Eds.; Springer: Berlin/Heidelberg, Germany, 2013; pp. 547-562. ISBN 978-3-642-39965-7.

49. Abbate, G.; Saraceno, E. What else is emerging from the horizon? In Advances in Sustainable Energy; Vasel, A., Ting, D., Eds.; Springer: Cham, Switzerland, 2019; Vol. 70, pp. 177-213. ISBN: 978-3-030-05635-3. 
50. Bronstein, M.G. Harnessing Rivers of Wind: A Technology and Policy Assessment of High Altitude Wind Power in the US. Technol. Forecast Soc. Change 2011, 78, 736-746, doi:10.1016/j.techfore.2010.10.005.

51. Girrbach, F.; Hol, J.D.; Bellusci, G.; Diehl, M. Towards Robust Sensor Fusion for State Estimation in Airborne Applications Using GNSS and IMU. IFAC-PapersOnLine 2017, 50, 13264-13269, doi:10.1016/j.ifacol.2017.08.1963.

52. Sommerfeld, M. Optimal Performance of Airborne Wind Energy Systems Subject to Realistic Wind Profiles. Ph.D. Dissertation, University of Victoria, Victoria, BC, Canada, 2020. https://dspace.library.uvic.ca/handle/1828/12559 (accessed 26 October 2021).

53. Archer, C.L.; Delle Monache, L.; Rife, D.L. Airborne Wind Energy: Optimal Locations and Variability. Renew. Energ. 2014, 64, 180-186, doi:10.1016/j.renene.2013.10.044.

54. Gulabani, G.; Karim, B.S.A.; Radhakrishnan, J.; Satish, B.S.; Zuber, M. Review on Unconventional Wind Energy. J. Eng. Technol. Sci. 2020, 52, 565-583, doi:10.5614/J.ENG.TECHNOL.SCI.2020.52.4.8.

55. Salma, V.; Ruiterkamp, R.; Kruijff, M.; van Paassen, M.M.; Schmehl, R. Current and Expected Airspace Regulations for Airborne Wind Energy Systems. In Airborne Wind Energy. Green Energy and Technology; Schmehl, R., Ed.; Springer: Singapore, 2018; pp. 703-725. ISBN 978-981-10-1947-0.

56. Bauer, F. Multidisciplinary Optimization of Drag Power Kites. Ph.D. Dissertation, Technical University of Munich, Munich, Germany, 2019. https://mediatum.ub.tum.de/1484087 (accessed 13 September 2021).

57. de Lellis, M. Airborne Wind Energy with Tethered Wings: Modeling, Analysis and Control. Ph.D. Dissertation, Federal University of Santa Catarina, Florianópolis, Santa Catarina, Brazil, 2016. https://repositorio.ufsc.br/handle/123456789/173661 (accessed on 30 October 2021).

58. Cherubini, A.; Vertechy, R.; Fontana, M. Simplified Model of Offshore Airborne Wind Energy Converters. Renew. Energ. 2016, 88, 465-473, doi:10.1016/j.renene.2015.11.063.

59. Roberts, B.W.; Shepard, D.H.; Caldeira, K.; Cannon, M.E.; Eccles, D.G.; Grenier, A.J.; Freidin, J.F. Harnessing High-Altitude Wind Power. IEEE Trans. Energy Convers. 2007, 22, 136-144, doi:10.1109/TEC.2006.889603.

60. Roberts, B.W. Quad-Rotorcraft to Harness High-Altitude Wind Energy. In Airborne Wind Energy. Green Energy and Technology; Schmehl, R., Ed.; Springer: Singapore, 2018; pp. 581-601. ISBN 978-981-10-1947-0.

61. RenewableUK. Onshore Wind Health \& Safety Guidelines, 2015. Health \& Safety. https://www.renewableuk.com/page/HealthSafety (accessed on 25 October 2021).

62. Alonso-Pardo, J.; Sánchez-Arriaga, G. Kite Model with Bridle Control for Wind-Power Generation. J. Aircr. 2015, 52, 917923, doi:10.2514/1.C033283.

63. de Lellis, M.; Mendonça, A.K.; Saraiva, R.; Trofino, A.; Lezana, A. Electric Power Generation in Wind Farms with Pumping Kites: An Economical Analysis. Renew. Energ. 2016, 86, 163-172, doi:10.1016/j.renene.2015.08.002.

64. Malz, E.C. Airborne Wind Energy - to Fly or Not to Fly? A Study on the Power Production of Airborne Wind Energy Systems and Their Integration in the Electricity Generation System. Ph.D. Dissertation, Chalmers University of Technology, Göteborg, Sweden, 2020. https://research.chalmers.se/en/publication/518841 (accessed on 30 October 2021).

65. Fagiano, L.; Milanese, M.; Piga, D. High-Altitude Wind Power Generation. IEEE Trans. Energy Convers. 2010, 25, 168-180, doi:10.1109/TEC.2009.2032582.

66. Bosch, A.; Schmehl, R.; Tiso, P.; Rixen, D. Dynamic Nonlinear Aeroelastic Model of a Kite for Power Generation. J. Guid. Control Dyn. 2014, 37, 1426-1436, doi:10.2514/1.G000545.

67. Jehle, C.; Schmehl, R. Applied Tracking Control for Kite Power Systems. J. Guid. Control Dyn. 2014, 37, 1211-1222, doi:10.2514/1.62380.

68. Key De Souza Mendonça, A.; Guerra Braga, T.; Bornia, A.C. Airborne Wind Energy Systems: Current State and Challenges to Reach the Market. In Proceedings of the International Joint Conference on Industrial Engineering and Operations 2020.

69. Khan, Z.; Rehan, M. Harnessing Airborne Wind Energy: Prospects and Challenges. J. Control. Autom. Electr. Syst. 2016, 27, 728-740, doi:10.1007/S40313-016-0258-Y

70. Knopper, L.D.; Ollson, C.A.; Mccallum, L.C.; Whitfield Aslund, M.L.; Berger, R.G.; Souweine, K.; Mcdaniel, M.; Ma, Y. Wind Turbines and Human Health. Front. Public Health 2014, 2:63, doi:10.3389/fpubh.2014.00063.

71. Hanna, C. Airborne Wind Demonstration Site (Ireland). Volume 3 - Planning \& Environment Report with Appendix, 2020. Planning Application Details Ref: 20713 Mayo County http://www.eplanning.ie/MayoCC/AppFileRefDetails/20713/0 (accessed 1 October 2021).

72. Omexom Renewable Energies Offshore GmbH (Oldenburg, Germany). Unpublished work, 2020.

73. Bruinzeel, L.; Klop, E.; Brenninkmeijer, A.; Bosch, J. Ecological impact of airborne wind energy technology: current state of knowledge and future research agenda. In Airborne Wind Energy. Green Energy and Technology; Schmehl, R., Ed.; Springer: Singapore, 2018; pp. 679-701 ISBN 10.1007/9789811.

74. van der Vlugt, R.; Peschel, J.; Schmehl, R. Design and Experimental Characterization of a Pumping Kite Power System. In Airborne Wind Energy. Green Energy and Technology; Ahrens, U., Diehl, M., Schmehl, R., Eds.; Springer: Berlin, Heidelberg, Germany, 2013; pp. 403-425.

75. Håland, A. Testing of Kitemill's Airborne Wind Energy System at Lista, Norway. Assessing the Impacts on Birds. A Pilot Study.; Bergen, 2018;

76. Omexom Renewable Energies Offshore GmbH (Oldenburg, Germany). Unpublished work, 2020.

77. David, R.E.; Kawahara, K.C. Bird and Bat Conservation Plan - Makani Energy Kite Project, South Kohala District, Island of Hawai'i, Hawai'i, 2018. Working Group “Environment and Public Acceptance”. https://airbornewindeurope.org/about- 
airborne-wind-europe/working-groups/working-group-environment-and-public-acceptance/ (accessed on 30 October 2021).

78. Tulloch, O. Modelling and Analysis of Rotary Airborne Wind Energy Systems-a Tensile Rotary Power Transmission Design. Ph.D. Dissertation, University of Strathclyde, Glasgow, Scotland, 2021. https://www.researchgate.net/publication/351443078_Modelling_and_Analysis_of_Rotary_Airborne_Wind_Energy_Syste ms_-_a_Tensile_Rotary_Power_Transmission_Design\#fullTextFileContent (accessed on 13 October 2021).

79. Malz, E.C.; Walter, V.; Göransson, L.; Gros, S. The Value of Airborne Wind Energy to the Electricity System. Wind Energy 2021, 1-19, doi:10.1002/WE.2671.

80. Molnarova, K.; Sklenicka, P.; Stiborek, J.; Svobodova, K.; Salek, M.; Brabec, E. Visual Preferences for Wind Turbines: Location, Numbers and Respondent Characteristics. Appl. Energy 2012, 92, 269-278, doi:10.1016/J.APENERGY.2011.11.001.

81. Betakova, V.; Vojar, J.; Sklenicka, P. Wind Turbines Location: How Many and How Far? Appl. Energy 2015, 151, 23-31, doi:10.1016/J.APENERGY.2015.04.060.

82. Cherubini, A. Advances in Airborne Wind Energy and Wind Drones, 2017. Ph.D. Dissertation, University Sant'Anna, Pisa, Italy, 2017. 2021. https://www.antonellocherubini.com/uploads/4/5/7/1/45719075/cherubini_phd_thesis_small.pdf (accessed on 3 September 2021).

83. Cherubini, A.; Moretti, G.; Fontana, M. Dynamic Modeling of Floating Offshore Airborne Wind Energy Converters. In Airborne Wind Energy. Green Energy and Technology; Schmehl, R., Ed.; Springer: Singapore, 2018; pp. 137-163. ISBN $10.1007 / 9789811$.

84. Fagiano, L.; Milanese, M. Airborne Wind Energy: An Overview. In Proceedings of the American Control Conference, Montreal, Canada, 27-29 June 2012; pp. 3132-3143.

85. Ladenburg, J.; Hevia-Koch, P.; Petrović, S.; Knapp, L. The Offshore-Onshore Conundrum: Preferences for Wind Energy Considering Spatial Data in Denmark. Renew. Sust. Energ. Rev. 2020, 121, 109711, doi:10.1016/J.RSER.2020.109711.

86. Ferguson, M.D.; Evensen, D.; Ferguson, L.A.; Bidwell, D.; Firestone, J.; Dooley, T.L.; Mitchell, C.R. Uncharted Waters: Exploring Coastal Recreation Impacts, Coping Behaviors, and Attitudes towards Offshore Wind Energy Development in the United States. Energy Res. Soc. Sci. 2021, 75, 102029, doi:10.1016/J.ERSS.2021.102029.

87. Petrova, M.A. NIMBYism Revisited: Public Acceptance of Wind Energy in the United States. Wiley Interdiscip. Rev. Clim. Change 2013, 4, 575-601, doi:10.1002/wcc.250.

88. Lu, H.; Song, H.; McComas, K. Seeking Information about Enhanced Geothermal Systems: The Role of Fairness, Uncertainty, Systematic Processing, and Information Engagement Intentions. Renew. Energ. 2021, 169, 855-864, doi:10.1016/J.RENENE.2021.01.031.

89. Jobin, M.; Visschers, V.H.M.; van Vliet, O.P.R.; Árvai, J.; Siegrist, M. Affect or Information? Examining Drivers of Public Preferences of Future Energy Portfolios in Switzerland. Energy Res. Soc. Sci. 2019, 52, 20-29, doi:10.1016/J.ERSS.2019.01.016.

90. Hahnel, U.J.J.; Mumenthaler, C.; Spampatti, T.; Brosch, T. Ideology as Filter: Motivated Information Processing and Decision-Making in the Energy Domain. Sustainability 2020, 12, 8429, doi:10.3390/SU12208429.

91. Ahmed, M.; Hably, A.; Bacha, S. High Altitude Wind Power Systems: A Survey on Flexible Power Kites. In Proceedings of the 2012 XXth International Conference on Electrical Machines, Marseille, France, 2-5 September 2012; pp. $2085-2091$.

92. Chihaia, R.-A.; Nicolaie, S.; Cîrciumaru, G.; El-Leathey, A.; Constantin, D. Market Potential of Unconventional Wind Turbines. A Technology Review. In Proceedings of International Conference on Hydraulics, Pneumatics, Sealing Elements, Tools, Precision Mechanics, Specific Electronic Equipment \& Mechatronics, Baile Govora, Romania, 13-15 November 2019; pp. 159-168.

93. Luetsch, G. High Altitude Wind Power Plants: Dealing with the Risks. In Proceedings of the 11th AIAA Aviation Technology, Integration, and Operations (ATIO) Conference; Virginia Beach, VA, USA, 20-22 September 2011; American Institute for Aeronautics and Astronautics: 2012.

94. Kamp, L.M.; Ortt, J.R.; Doe, M.F.A. Niche Strategies to Introduce Kite-Based Airborne Wind Energy. In Airborne Wind Energy. Green Energy and Technology; Schmehl, R., Ed.; Springer: Singapore, 2018; pp. 665-678. ISBN 978-981-10-1947-0.

95. Aitken, M. Why We Still Don't Understand the Social Aspects of Wind Power: A Critique of Key Assumptions within the Literature. Energy Policy 2010, 38, 1834-1841, doi:10.1016/J.ENPOL.2009.11.060.

96. Rudolph, D.; Clausen, L.T. Getting Used to It, But ...? Rethinking the Elusive U-Curve of Acceptance and Post-Construction Assumptions. In A critical approach to the social acceptance of renewable energy infrastructures; Batel, S., Rudolph, D., Eds.; Palgrave Macmillan: Cham, Switzerland, 2021; pp. 63-81. ISBN 978-3-030-73699-6.

97. de Vries, G.; Terwel, B.W.; Ellemers, N. Perceptions of Manipulation and Judgments of Illegitimacy: Pitfalls in the Use of Emphasis Framing When Communicating about CO2 Capture and Storage. Environ. Commun. 2016, 10, 206-226, doi:10.1080/17524032.2015.1047884.

98. Batel, S.; Rudolph, D. Contributions, tensions and future avenues of a critical approach to the social acceptance of renewable energy infrastructures. In A critical approach to the social acceptance of renewable energy infrastructures; Batel, S., Rudolph, D., Eds.; Palgrave Macmillan: Cham, Switzerland, 2021; pp. 237-257. ISBN 978-3-030-73699-6.

99. Walker, G.; Devine-Wright, P.; Barnett, J.; Burningham, K.; Cass, N.; Devine-Wright, H.; Speller, G.; Barton, J.; Evans, B.; Heath, Y.; et al. Symmetries, expectations, dynamics and contexts: A framework for understanding public engagement with renewable energy projects. In Renewable Energy and the Public; Routledge, 2010; pp. 33-46.

100. Batel, S.; Devine-Wright, P. Towards a Better Understanding of People's Responses to Renewable Energy Technologies: Insights from Social Representations Theory, Public Underst. Sci. 2014, 24, 311-325, doi:10.1177/0963662513514165. 
101. Sherren, K.; Chappell, E.; Parkins, J. Strategies for Integrating Quantitative Methods into Critical Social Acceptance Research. In A critical approach to the social acceptance of renewable energy infrastructures; Batel, S., Rudolph, D., Eds.; Palgrave Macmillan: Cham, Switzerland, 2021; pp. 23-42. ISBN 978-3-030-73699-6.

102. Batel, S. Research on the Social Acceptance of Renewable Energy Technologies: Past, Present and Future. Energy Res. Soc. Sci. 2020, 68, 101544, doi:10.1016/J.ERSS.2020.101544.

103. Upham, P.; Oltra, C.; Boso, À. Towards a Cross-Paradigmatic Framework of the Social Acceptance of Energy Systems. Energy Res. Soc. Sci. 2015, 8, 100-112, doi:10.1016/j.erss.2015.05.003.

104. Huijts, N.M.A.; Molin, E.J.E.; Steg, L. Psychological Factors Influencing Sustainable Energy Technology Acceptance: A Review-Based Comprehensive Framework. Renew. Sust. Energ. Rev. 2012, 16, 525-531, doi:10.1016/J.RSER.2011.08.018.

105. Phadke, R. Public Deliberation and the Geographies of Wind Justice. Sci. Cult. 2013, 22, 247-255, doi:10.1080/09505431.2013.786997.

106. Boomsma, C.; ter Mors, E.; Jack, C.; Broecks, K.; Buzoianu, C.; Cismaru, D.M.; Peuchen, R.; Piek, P.; Schumann, D.; Shackley, S.; et al. Community Compensation in the Context of Carbon Capture and Storage: Current Debates and Practices. Int. J. Greenh. Gas Control 2020, 101, 103128, doi:10.1016/J.IJGGC.2020.103128. 